\title{
Pertinent spatio-temporal scale of observation to understand suspended sediment yield control factors in the Andean region: the case of the Santa River (Peru)
}

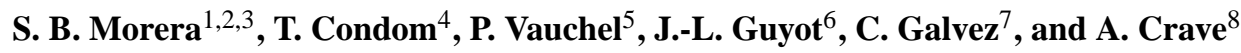 \\ ${ }^{1}$ Geosciences Environnement Toulouse, 14 avenue Edouard-Belin, Toulouse, France \\ ${ }^{2}$ Instituto Geofísico del Perú, Calle Badajoz \# 169 - Ate Vitarte, Lima 3, Peru \\ ${ }^{3}$ Universidad Agraria La Molina, Av. Universidad s/n, La Molina, Lima 12, Peru \\ ${ }^{4}$ Univ. Grenoble Alpes, CNRS, IRD, LTHE (UMR5564), 38000 Grenoble, France \\ ${ }^{5}$ Laboratoire des Mécanismes de Transferts en Géologie - UMR5563 CNRS-UPS-IRD, Toulouse, France \\ ${ }^{6}$ Institut de Recherche pour le Développement, Lima, Peru \\ ${ }^{7}$ Proyecto especial CHAVIMOCHIC, Trujillo, Peru \\ ${ }^{8}$ Geosciences Rennes, Centre National of Research Scientific, Rennes, France
}

Correspondence to: S. B. Morera (sergiobaymorera@gmail.com)

Received: 16 December 2012 - Published in Hydrol. Earth Syst. Sci. Discuss.: 15 January 2013

Revised: 6 October 2013 - Accepted: 22 October 2013 - Published: 26 November 2013

\begin{abstract}
Hydro-sedimentology development is a great challenge in Peru due to limited data as well as sparse and confidential information. This study aimed to quantify and to understand the suspended sediment yield from the westcentral Andes Mountains and to identify the main erosioncontrol factors and their relevance. The Tablachaca River $\left(3132 \mathrm{~km}^{2}\right)$ and the Santa River $\left(6815 \mathrm{~km}^{2}\right)$, located in two adjacent Andes catchments, showed similar statistical daily rainfall and discharge variability but large differences in specific suspended-sediment yield (SSY). In order to investigate the main erosion factors, daily water discharge and suspended sediment concentration (SSC) datasets of the Santa and Tablachaca rivers were analysed.

Mining activity in specific lithologies was identified as the major factor that controls the high SSY of the Tablachaca $\left(2204 \mathrm{t} \mathrm{km}^{2} \mathrm{yr}^{-1}\right)$, which is four times greater than the Santa's SSY. These results show that the analysis of control factors of regional SSY at the Andes scale should be done carefully. Indeed, spatial data at kilometric scale and also daily water discharge and SSC time series are needed to define the main erosion factors along the entire Andean range.
\end{abstract}

\section{Introduction}

Understanding erosion-control factors is a great challenge that would improve the modelling of climate-change impacts on mountain range dynamics or human impacts on the environment. Natural systems with large gradients of sediment yield production are of great interest for testing their sensitivity to erosion-control factors. Mountain ranges are good candidates because at a global scale they are the places with the largest erosion rates, climate gradients, slope gradients and seismicity processes. Among mountain ranges worldwide, the Andes range is particularly interesting because it crosses all terrestrial climates from north to south and has sharp eastwest climatic gradients, passing from a tropical climate to the world's driest desert in its central region. Montgomery et al. (2001) show that, at the Andes scale, topographic characteristics match the mean annual precipitation and the theoretical erosion index intensity (product of the local slope with the upstream rainfall amount). These authors suggest that this correlation indicates that climate is a first-order factor for the topographic evolution of the Andes.

Another approach is to analyse modern suspendedsediment yield (SSY) databases. Due to the limited amount of publicly available SSY data from Andean catchments, only a few studies have reviewed the relation between 
erosion factors and SSY there (e.g. Aalto et al., 2006; Armijos et al., 2013; Laraque et al., 2009; Molina et al., 2007, 2008; Pépin et al., 2010; Restrepo et al., 2006a; Guyot, 1993). In the northern Andes, mean annual runoff explained most SSY variability in the Magdalena River catchment and sub-catchments (Restrepo et al., 2006b). However, this study only explored hydrologic, morphometric and climatic factors and cannot explore vegetation, soil properties and the effect of land use because of a lack of information about these parameters. Conversely, Aalto et al. (2006) observed no relation between runoff and SSY in a database of $47 \mathrm{Bo}-$ livian catchments. On the other hand, lithology and slopes had the highest correlations with SSY in the Bolivian Andes. This study, however, mainly focused on geomorphic, hydrologic and lithologic parameters without any information about vegetation or land-use parameters for connected subcatchments. Pépin et al. (2010) performed a complete study of SSY in 66 Chilean catchments of similar size along the Andes, from extreme northern Chile to southern Patagonia, covering a wide range of climate, slopes and vegetation. This study showed that SSY had a linear relation with slope and runoff above and below threshold values related to vegetation cover, respectively. Lithology and seismicity have also been explored but have not given reliable results due to the nonexhaustiveness of these data in Chile. On the eastern side of the northern and central Andes, SSY had the highest positive correlation with rainfall variability and negative correlation with mean annual rainfall (Pépin et al., 2013). At the hillslope scale $\left(<1 \mathrm{~km}^{2}\right)$, Molina et al. $(2007,2008)$ showed that SSY is well correlated with cover, soil types and road networks, based on a database of 37 small sub-catchments of the Paute River (Ecuador).

Despite the particular climatic configuration of the Andes, these studies cannot give a clear view of the relative dominance of erosion-control factors. Actually, a nonnegligible area of the western Andes is not documented due to the scarcity of available and reliable data on SSY there. Among other factors, the rugged Andean piedmont topography and extreme east-west climatic gradients with large rainfall-event variability are some characteristics of this region often proposed as main erosion-control factors. Therefore, collecting SSY data from the west-central Andes is of primary interest to deepen understanding of erosion factors in the Andes.

In this study, a new daily SSY dataset from the central Andes in Peru was analysed during collaboration between the CHAVIMOCHIC (http://www.chavimochic.gob. pe/) and HYBAM (http://www.ore-hybam.org/) projects. Reliable suspended sediment concentration (SSC) data have been collected since 1999 by the Peruvian irrigation CHAVIMOCHIC project. It monitors sediment in the lower section of the Santa River catchment at three stream discharge and sediment load gauging stations. The Santa River catchment, located in the west-central Andes, has strong altitudinal gradients, with high topographic contrast with elevations ranging from sea level to the highest point in the central Andes (Nevado Huascaran; $6768 \mathrm{~m}$ a.s.1.). The seasonal and low vegetation cover, poorly consolidated lithology, and weather all change significantly over relatively short distances, and the east-west rainfall gradient ranges from 151 to $1115 \mathrm{~mm} \mathrm{yr}^{-1}$ (1998-2010). In addition, there is intense human activity such as small- and large-scale mining of coal, metal and aggregates distributed from the coast to the highlands (Morera, 2010).

In analysing this exceptional SSC dataset, we identify two adjacent catchments that have significant differences in their SSY despite having similar climatic and hydrologic contexts. This is a good example for improving understanding about which factors control the magnitude and frequency of SSY from the west-central Andes to the Pacific coast, with a special focus on (i) spatial differences in sediment production at the basin scale (few thousand $\mathrm{km}^{2}$ ), (ii) non-climatic erosion factors such as mine activity in specific lithology, and (iii) the relevant resolution of maps necessary to define erosion factors in the central Andes. In addition, the SSY of the Santa River is compared to SSY observed in the Andes range from $35^{\circ} \mathrm{S}$ to $10^{\circ} \mathrm{N}$.

\section{Study area, dataset and methods}

\subsection{Geographic description and geomorphological characteristics of the Santa and Tablachaca sub-catchments}

The Santa River is one of the largest rivers that empty into the Pacific Ocean in Peru, with a total length of $316 \mathrm{~km}$ and a drainage area of $12000 \mathrm{~km}^{2}$. It is situated in northwestern Peru, between 7.9 and $10.1^{\circ} \mathrm{S}$ and between 78.6 and $77.2^{\circ} \mathrm{E}$. This study focuses on two stations (subcatchments) of the Santa River that are geographically close to each other (Fig. 1): the Santa station (507 m a.s.1.), covering the middle and upper Santa catchment $\left(6815 \mathrm{~km}^{2}\right)$, and the Tablachaca station (524 ma.s.1.), which monitors the whole Tablachaca sub-catchment $\left(3132 \mathrm{~km}^{2}\right)$. Both stations are controlled downstream at the Condorcerro station (479 ma.s.l.), which monitors $9969 \mathrm{~km}^{2}$ from 479 to $6768 \mathrm{~m}$ a.s.1.

The Santa sub-catchment drains from southeast to northwest and is defined by the Cordillera Blanca on the east and the Cordillera Negra, with lower topography, on the west (Fig. 1). The Cordillera Blanca is located in the western branch of the Andes in Peru and is the highest and most extensive expanse of tropical glaciers in the world (Zapata et al., 2008). It represents approximately $35 \%\left(600 \mathrm{~km}^{2}\right)$ of the total area of Peruvian glaciers and $\sim 10 \%$ of the total catchment; also, it contains the Huascaran peak, which at $6768 \mathrm{~m}$ a.s.l. is the second highest point in the central Andes (Georges, 2004). It is the only example of an active, large-magnitude extension with a pronounced footwall 


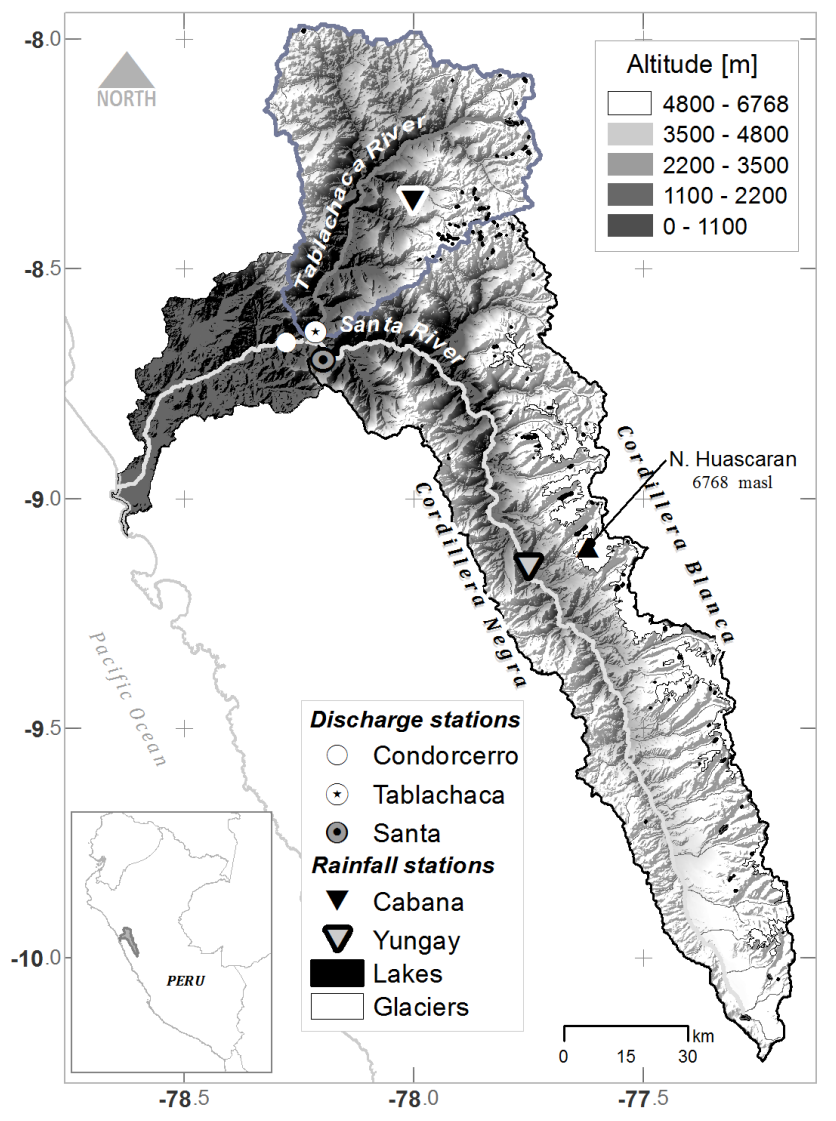

Fig. 1. Shaded-relief and elevation map of the Santa and Tablachaca study catchments in the west-central Andes (SRTM, 2002). Circles indicate locations of the monitoring stations.

topography (McNulty and Farber, 2002). Finally, the Santa sub-catchment has a rugged topography with steep slopes in higher parts of the range and contains more than 15 peaks higher than $6000 \mathrm{~m}$ a.s.l. (Schwartz, 1988). In contrast, northwards, the Tablachaca sub-catchment extends from northeast to southwest of the high mountain ranges, which range from 479 to $\sim 5000 \mathrm{~m}$ a.s.l. and have a scarcity of glaciers. Natural setting of the Tablachaca sub-watershed with strong altitudinal gradient creates highly vulnerable watersheds with deeper and smaller rivers than the Santa sub-watershed.

\subsection{Lithological parameters}

Regional geology includes sedimentary and igneous rocks from the Triassic to the Quaternary period (Table 1), as shown in the detailed lithological map at 1:100000 scale (Fig. 2). Nine different lithology types (or codes) were distinguished. Lithological information and formation ages were collected from geological studies carried out by the National Development Institute (INADE), Giovanni et al. (2010), Carrascal-Miranda and Suárez-Ruiz (2004), Klimeš et al. (2009), Wilson et al. (1967) and Schwartz (1988).

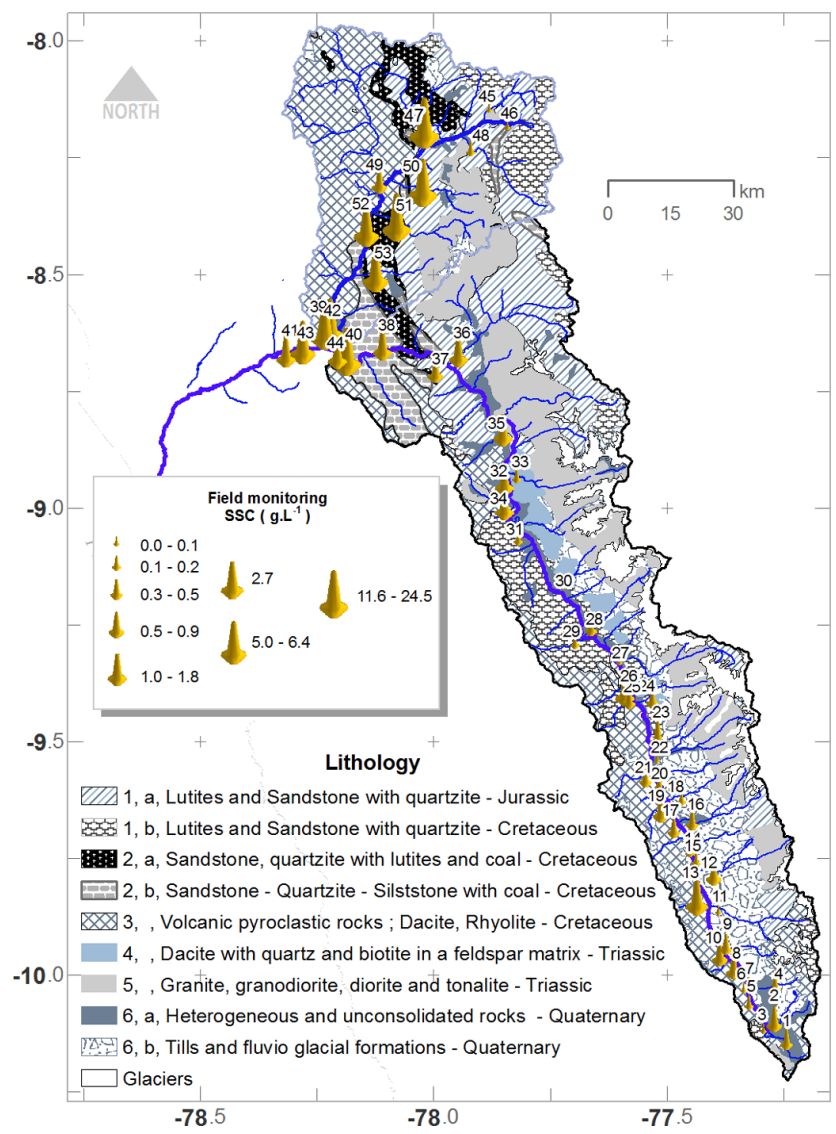

Fig. 2. Lithology map of the Santa and Tablachaca study catchments according to six formations (details in Table 1). Cones size according to suspended sediment concentration amount (SSC, $\mathrm{gL}^{-1}$ ) sampled during the wet season (February-March 2009; see Table 2 for details).

Lithology of the Santa sub-catchment is composed mainly of (i) dacite with quartz and biotite in a feldspar matrix (code 4) and heterogeneous and unconsolidated rocks in the centre of the Cordillera Blanca range (code 6a); (ii) Tertiary rocks producing colluvium, covered in some areas by glacial till and rock-debris avalanche deposits further transformed by water erosion in the upper Santa River Valley (code 6b); (iii) lutites and sandstone with quartzite (code 1b) and granite, granodiorite, diorite and tonalite (code 5) overlain by clastic sediments deposited during the glacial retreat from the Cordillera Blanca; and (iv) lutites and sandstone with quartzite (code 1b) and volcanic rocks such as rhyolite (code 3) are widely exposed along the Cordillera Negra.

Lithology of the Tablachaca sub-catchment is composed mainly of (i) volcanic pyroclastic rocks (code 3) in the northwest and southwest; (ii) granite, granodiorite, diorite and tonalite (code 5) and lutites and sandstone with quartzite (codes 1a and 1b) in the northeast; (iii) sandstone-quartzitesiltstone with coal in the lower northeast (code 2b); and (iv) quartzite with lutites and coal distributed between the 
Table 1. Lithological typology in the study catchments.

\begin{tabular}{|c|c|c|c|c|}
\hline Code & Lithology & Formation & Period & Description \\
\hline $1 \mathrm{a}$ & $\begin{array}{l}\text { Lutites and sandstone } \\
\text { with quartzite }\end{array}$ & Chicama & Jurassic & $\begin{array}{l}\text { Most consist of dark grey laminated shale } \\
\text { and fine grey and clear sandstone with } \\
\text { quartzite. }\end{array}$ \\
\hline $1 b$ & $\begin{array}{l}\text { Lutites and sandstone } \\
\text { with quartzite }\end{array}$ & Goyllarisquizga & Cretaceous & $\begin{array}{l}\text { Silt } 80-95 \% \text {, sand (feldspar and quartz) } 0 \\
20 \% \text {, bitumen and coal } 0-5 \%\end{array}$ \\
\hline $2 \mathrm{a}$ & $\begin{array}{l}\text { Sandstone, quartzite with } \\
\text { lutites and coal }\end{array}$ & Chimu & Cretaceous & $\begin{array}{l}\text { Quartz }>90 \% \text {, feldspar } \pm 5 \% \text {, silica colloid } \\
\pm 5 \%\end{array}$ \\
\hline $2 \mathrm{~b}$ & $\begin{array}{l}\text { Sandstone-quartzite- } \\
\text { siltstone with coal }\end{array}$ & Santa-Carhuaz & Cretaceous & $\begin{array}{l}\text { Silt } 80-95 \% \text {, sand (feldspar and quartz) } 0- \\
20 \% \text {, bitumen and coal } 0-5 \%\end{array}$ \\
\hline 3 & $\begin{array}{l}\text { Volcanic pyroclastic rocks: } \\
\text { dacite, rhyolite }\end{array}$ & Calipuy & Cretaceous & $\begin{array}{l}\text { Plagioclase } 70-80 \% \text {, hornblende } 20-25 \% \text {, } \\
\text { magnetite }\end{array}$ \\
\hline 4 & $\begin{array}{l}\text { Dacite with quartz and biotite in } \\
\text { a feldspar matrix }\end{array}$ & Yungay & Triassic & $\begin{array}{l}\text { Dacitic tuffs with abundant quartz and bi- } \\
\text { otite crystals in a matrix of feldspar, con- } \\
\text { taining angular rock fragments around them }\end{array}$ \\
\hline 5 & $\begin{array}{l}\text { Granite, granodiorite, diorite } \\
\text { and tonalite }\end{array}$ & $\begin{array}{l}\text { Granodiorite- } \\
\text { Tonalite }\end{array}$ & Triassic & $\begin{array}{l}\text { Plagioclase } 42 \% \text {, orthoclase } 12 \% \text {, biotite } \\
9 \% \text {, hornblende } 4 \% \text {, quartz } 20 \%\end{array}$ \\
\hline $6 a$ & $\begin{array}{l}\text { Heterogeneous and } \\
\text { unconsolidated rocks }\end{array}$ & Aluvial & Quaternary & $\begin{array}{l}\text { Semi-consolidated sand, clay, and gravel } \\
\text { conglomerates, generally horizontal }\end{array}$ \\
\hline $6 b$ & $\begin{array}{l}\text { Tills and fluvio-glacial } \\
\text { formations }\end{array}$ & Fluvio-Glacial & Quaternary & $\begin{array}{l}\text { Morainic accumulations are composed and } \\
\text { filled with sand, clay and gravel. Rock frag- } \\
\text { ments are heterometric, little selected and } \\
\text { angular and sub-rounded. }\end{array}$ \\
\hline
\end{tabular}

mountain range and the main river (code $2 a$ ). The two series composed of coal basins (codes $2 \mathrm{a}$ and $2 \mathrm{~b}$ ) are related to different orogenic events that strongly affected this region. The most important distributions (code 2a), however, came from Mesozoic-Chimu coal (Petersen, 2010). Note that the Fig. 2 also contains field monitoring results, which will be discussed in the Sects. 3.3 and 3.5.

\subsection{Land-use parameters and mining activity}

Land-use data were processed from high-resolution $(30 \times$ $30 \mathrm{~m}$ ) Landsat-7 ETM images downloaded from the US Geological Survey's Earth Explorer (http://earthexplorer.usgs. gov/). We downloaded three image mosaics from June to July 2006 (a period of fewer clouds and relative stability in vegetation cover) encompassing the entire study area and then analysed them by classifying spectral bands 2, 3 and 4 (Adams et al., 1995).

We first evaluated the main land-cover areas using GPS points that were well distributed throughout the catchment, such as forests, crops, slide areas, rocks, mines, towns, glaciers, water bodies and areas of dark soil due to exposed coal. We then performed supervised classification of land cover with ERDAS software according to Göttlicher et al. (2009), based on GPS points already taken in the catchment and the use of Google Earth to view points that could not be physically reached (e.g. glaciers). The mosaic images were georeferenced and normalised, and land cover was classified into six dominant types: rock, glacier, woodland, urban, mine and bare soil (e.g. Tao et al., 2012; Ward et al., 2009).

Significant human effort went into mining and mineral production in ancient Peru; this human activity dominated the landscape of the inter-Andean valleys on a temporal scale ranging from years to centuries (Harden, 2006; Petersen, 2010; Tarras-Wahlberg and Lane, 2003). Ever since the Spanish conquered the Incas, the Andes zone has been known for its deposits of gold, silver, coal and other valuable metals (United Nations, 1990). Coal was used in pre-Inca times for metallurgy, and its first large-scale industrial application occurred around 1816 for steam generation at copper mines (Agramonte and Diaz, 1983). An example of the vast reserve of minerals within the Santa sub-catchment is the largest known copper-zinc skarn ore deposit, "Antamina" (e.g. Fig. 3), and it incorporates a mineral reserve of $561 \mathrm{Mt}$ (Love et al., 2004). Overall, the Santa River basin has major environmental problems, most of which are due to abandoned-mine tailings and related problems such as mine closure, poorly maintained tailings ponds, competition for scarce water supplies and smelter pollution (McMahon et al., 1999). As a consequence, water quality in the upper Santa sub-catchment is threatened by past and current mining and increasing near-stream disposal of domestic, industrial and mining waste as well as livestock grazing (Young and Lipton, 2006; BCRP, 2009).

There is little information on spatiotemporal changes in the current large-scale and artisanal mining activities in the study area because mining regulations are not well 
Table 2. Sites where samples were collected during the wet season 2009 (February-March) in the Santa and Tablachaca study catchments.

\begin{tabular}{|c|c|c|c|c|c|c|}
\hline Code & River name & $X$ & $Y$ & Date & $\mathrm{g} \mathrm{L}^{-1}$ & Observations \\
\hline 1 & Conococha & -77.28 & -10.12 & 23/2/2009 15:10 & 0.27 & Outlet of Lake Pelagatos \\
\hline 2 & Collota & -77.29 & -10.12 & 23/2/2009 15:20 & 0.06 & Little river coming from The Cordillera Blanca \\
\hline 3 & Santa & -77.28 & -10.11 & $23 / 2 / 200915: 30$ & 0.52 & Confluence \\
\hline 4 & Pariay & -77.26 & -10.02 & $23 / 2 / 200916: 30$ & 0.36 & Outlet of a small mine, Cordillera Blanca \\
\hline 5 & Recreta & -77.33 & -10.04 & 23/2/2009 17:00 & 0.09 & Hydrology station \\
\hline 6 & Ashjas & -77.33 & -10.02 & $23 / 2 / 200917: 18$ & 0.06 & From the Cordillera Blanca \\
\hline 7 & Santa & -77.33 & -10.02 & $23 / 2 / 200917: 34$ & 0.05 & The Santa River \\
\hline 8 & Pupuncancha & -77.36 & -9.97 & 23/2/2009 17:40 & 0.78 & From the Cordillera Blanca \\
\hline 9 & $\mathrm{SN}$ & -77.38 & -9.96 & $23 / 2 / 200917: 50$ & 0.37 & River coming from the Cordillera Negra \\
\hline 10 & Collota & -77.38 & -9.95 & 23/2/2009 18:10 & 0.64 & From the Cordillera Blanca \\
\hline 11 & Pachacoto & -77.40 & -9.85 & 23/2/2009 18:20 & 0.01 & Hydrology station \\
\hline 12 & Yanayacu & -77.42 & -9.78 & 23/2/2009 18:40 & 0.62 & From the Cordillera Blanca \\
\hline 13 & Utcuyacu & -77.42 & -9.82 & 23/2/2009 19:00 & 2.68 & From the Cordillera Negra \\
\hline 14 & Atoc Huacanca & -77.45 & -9.72 & $24 / 2 / 200909: 40$ & 0.21 & From the Cordillera Negra \\
\hline 15 & Chiriac & -77.45 & -9.74 & $24 / 2 / 200909: 50$ & 0.09 & From the Cordillera Negra \\
\hline 16 & Sipchoc & -77.46 & -9.69 & $24 / 2 / 2009$ 10:10 & 0.26 & From the Cordillera Negra \\
\hline 17 & Olleros & -77.48 & -9.67 & $24 / 2 / 200910: 15$ & 0.35 & From the Cordillera Blanca \\
\hline 18 & Ututo Pama & -77.50 & -9.63 & $24 / 2 / 2009$ 10:30 & 0.12 & From the Cordillera Blanca \\
\hline 19 & Entrada Huaraz & -77.51 & -9.61 & $24 / 2 / 200910: 50$ & 0.59 & Before urban Huaraz city \\
\hline 20 & Pariac & -77.52 & -9.58 & $24 / 2 / 200911: 10$ & 0.45 & From the Cordillera Blanca \\
\hline 21 & Santa & -77.53 & -9.58 & 24/2/2009 11:15 & 0.48 & After Huaraz city \\
\hline 22 & Quilcaihuanca & -77.52 & -9.53 & $24 / 2 / 200911: 50$ & 0.03 & From the Cordillera Blanca \\
\hline 23 & Santa & -77.54 & -9.47 & 24/2/2009 12:20 & 0.51 & Sampling after Huaraz city \\
\hline 24 & Paltay & -77.56 & -9.42 & $24 / 2 / 200912: 40$ & 0.27 & From the Cordillera Blanca \\
\hline 25 & Llacash & -77.58 & -9.40 & $24 / 2 / 200913: 15$ & 0.40 & Mining activity. From the Cordillera Blanca \\
\hline 26 & Poyor & -77.59 & -9.38 & $24 / 2 / 200913: 20$ & 1.03 & Poyro River. From the Cordillera Blanca \\
\hline 27 & Marcara & -77.60 & -9.32 & 24/2/2009 13:40 & 0.08 & Along a town. From the Cordillera Blanca \\
\hline 28 & Buin & -77.68 & -9.27 & 24/2/2009 14:00 & 0.37 & From the Cordillera Blanca \\
\hline 29 & Ampa & -77.68 & -9.28 & $24 / 2 / 200914: 40$ & 0.12 & From the Cordillera Negra \\
\hline 30 & Ranrahirca & -77.73 & -9.17 & 24/2/2009 15:30 & 0.03 & From the Cordillera Blanca \\
\hline 31 & Luyan & -77.82 & -9.04 & $24 / 2 / 200916: 00$ & 0.14 & From the Cordillera Blanca \\
\hline 32 & Santa & -77.84 & -8.94 & $24 / 2 / 200916: 50$ & 1.19 & After the Duke energy hydroelectric \\
\hline 33 & Puca & -77.84 & -8.97 & $24 / 2 / 2009$ 17:04 & 0.12 & From the Cordillera Negra \\
\hline 34 & Pte. Choquechac & -77.82 & -8.99 & $24 / 2 / 200917: 14$ & 1.19 & In the Santa River at Choquechac bridge \\
\hline 35 & Huaylas & -77.86 & -8.81 & $25 / 2 / 200907: 15$ & 1.14 & From the Cordillera Negra \\
\hline 36 & Manta & -77.97 & -8.69 & 25/2/2009 00:00 & 0.64 & After the Manta River \\
\hline 37 & Santa & -77.98 & -8.69 & 25/2/2009 08:30 & 1.17 & After the Santa River \\
\hline 38 & Santa & -78.08 & -8.66 & 25/2/2009 09:00 & 1.79 & After coal mining \\
\hline 39 & Tablachaca & -78.24 & -8.65 & 25/2/2009 09:45 & 11.61 & At Tablachaca station \\
\hline 40 & Santa & -78.23 & -8.66 & $25 / 2 / 200909: 50$ & 1.31 & At Santa station \\
\hline 41 & Boc. Chavimochic & -78.29 & -8.66 & 8/3/2009 11:00 & 1.44 & At Condorcerro station \\
\hline 42 & Tablachaca & -78.23 & -8.65 & $13 / 3 / 200917: 13$ & 15.04 & At Tablachaca station \\
\hline 43 & Condorcerro & -78.26 & -8.66 & $13 / 3 / 200918: 19$ & 6.35 & At Condorcerro station \\
\hline 44 & Santa & -78.23 & -8.65 & $10 / 3 / 200907: 22$ & 13.47 & Above the Tablachaca station \\
\hline 45 & Plata & -77.89 & -8.17 & $12 / 3 / 200908: 59$ & 0.04 & First river on the head cathment \\
\hline 46 & Pelagatos & -77.89 & -8.17 & 12/3/2009 09:07 & 0.06 & Origin of the Tablachaca River \\
\hline 47 & Tablachaca & -77.94 & -8.20 & $12 / 3 / 200911: 47$ & 5.11 & Before the confluence on the Pelagatos and Conchucos River \\
\hline 48 & Conchucos & -77.94 & -8.20 & $12 / 3 / 200911: 52$ & 0.10 & In the Conchucos River \\
\hline 49 & Huadoval & -78.09 & -8.30 & $12 / 3 / 200918: 26$ & 0.85 & In the Huandoval River \\
\hline 50 & Tablachaca & -78.10 & -8.30 & 13/3/2009 09:38 & 24.47 & After Angasmarca and Huandoval River \\
\hline 51 & Tablachaca & -78.14 & -8.37 & $13 / 3 / 200910: 58$ & 17.86 & After the confluence of the Santiago and Tablachaca rivers \\
\hline 52 & Boca Cabana & -78.14 & -8.37 & $13 / 3 / 200910: 59$ & 5.02 & In Boca Cabana River \\
\hline 53 & Ancos & -78.17 & -8.50 & $13 / 3 / 2009$ 14:24 & 4.97 & In Ancos River \\
\hline
\end{tabular}

enforced and the mines are typically located in remote areas (Tarras-Wahlberg and Lane, 2003) (Fig. 3). Thus, no relevant data are available for the volume of ore extracted from the mines or the volume of mineral waste and tailings.

\subsection{Slope and geomorphological characteristics}

Several datasets with geo-information are currently available, making it possible to derive catchment parameters from Shuttle Radar Topography Mission (SRTM) 3-arcsecond 


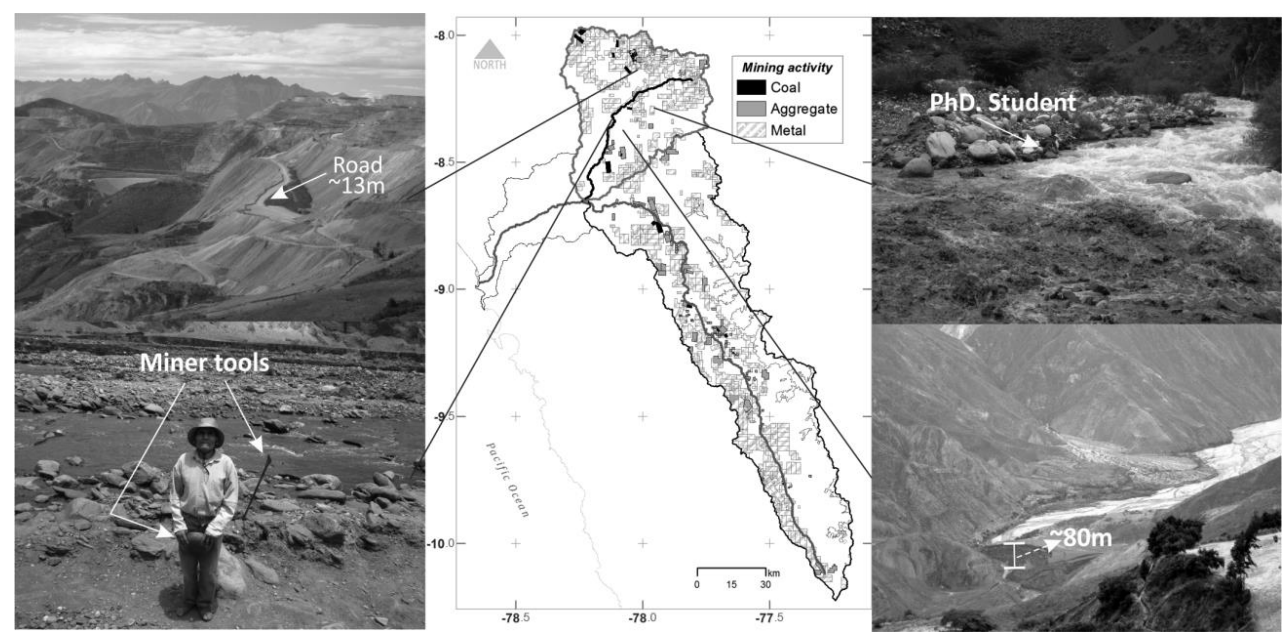

Fig. 3. The boom in large-scale mining in the upper basin (upper left) and an artisanal miner panning for gold during the dry season in the Tablachaca River (lower left). Distribution of mining concessions in the Santa River Basin (centre). The strong contrast between the higher SSC load carried by the Tablachaca River (left) and the lower SSC load in the Conchucos River (right) during the rainy season (upper right) and a landslide from the Chimu Formation creating a natural dam in the river bed many years ago (lower right).

$(\sim 90 \mathrm{~m} \times 90 \mathrm{~m})$ digital elevation model (DEM) distributed by the USGS National Map (http://seamless.usgs.gov/). The accuracy of the general dataset was calculated as $6.2 \mathrm{~m}$ of absolute height error by Rodríguez et al. (2006); however, Racoviteanu et al. (2007) estimated differences of $25 \mathrm{~m}$ at higher elevations and steeper slopes (glaciers). From this DEM we extracted the local slope in each pixel at a resolution of $8100 \mathrm{~m}^{2}$.

The basic configuration of the geomorphology, such as the mean slope, surface area, river networks, and height differences within each catchment, were calculated using GIS tools.

Next, spatial variability in local slope of the two subcatchments was analysed. The middle-altitude portion of the Santa sub-catchment is a deep, steep-walled canyon about $15 \mathrm{~km}$ long, at the bottom of which is a narrow verticalwalled slot up to several hundred metres deep called the "Cañon del Pato" (Ericksen et al., 1970). Higher elevations, starting from the central part of river valleys and extending upstream, have platforms that become planed surfaces near river headwaters that form flat areas $(68 \%$ of the whole area); in most cases, low slopes $\left(0-17^{\circ}\right)$ are most common. At the Cordillera Blanca, upper slopes are oversteepened, ranging from 45 to $90^{\circ}$, and locally unstable and sensitive to movements triggered by earthquakes (Klimeš et al., 2009). In contrast, the Cordillera Negra has lower slopes than the Cordillera Blanca and a relatively broad, gently undulating crest; valleys on the flanks are V-shaped and deeply incised at the bottom, indicating that they were cut by streams rather than glaciers. Finally, volcanic rocks on steep slopes of the Cordillera Negra are locally deeply weathered or strongly fractured and consequently are subject to sliding during the rainy seasons or in response to seismic movements (Ericksen et al., 1970). The slope morphology of the Tablachaca subcatchment is generally very steep $\left(40^{\circ}\right)$, while $30 \%$ is gently sloping in the northwest and southwest and $20 \%$ is very gentle. The strong altitudinal gradient of the Tablachaca subcatchment creates highly vulnerable slopes drained by deeper and smaller rivers than the Santa sub-catchment.

\subsection{Climate and rainfall}

Annual mean precipitation has high variability, ranging from 151 to $1115 \mathrm{~mm}$ from west to east in the study area (above Condorcerro station). It has two distinct climates, with a high-contrast gradient from the sea to the Andean Cordillera (e.g. Smith, 1979).

The first climate zone, the arid coast, is located from the lowlands to the foot of the Andes. This desert area is created by a cold southerly wind coming from the Pacific Ocean that forces subsidence to maintain a thermal balance, which triggers drying within this region and maintains an inversion layer at about $1000 \mathrm{~m}$ a.s.l. Moreover, mean annual precipitation $<10 \mathrm{~mm}$ is common along the coast and over the pre-Andean Central Depression (at about 1000 ma.s.l.). Finally, most of the precipitation that does fall is drizzle from the coastal stratus and unusual rainfall episodes associated with the passage of a cold front (Garreaud and Fuenzalida, 2007; Garreaud and Rutllant, 1996; Vargas et al., 2006). In the second climate zone, precipitation is dominated by southward expansion of upper-tropospheric easterlies during the austral summer, associated with intensification of the South American summer monsoon (Garreaud, 2009). Nonetheless, precipitation decreases when the northern tropical Atlantic Ocean is warmer than usual (Lavado et al., 2012). 

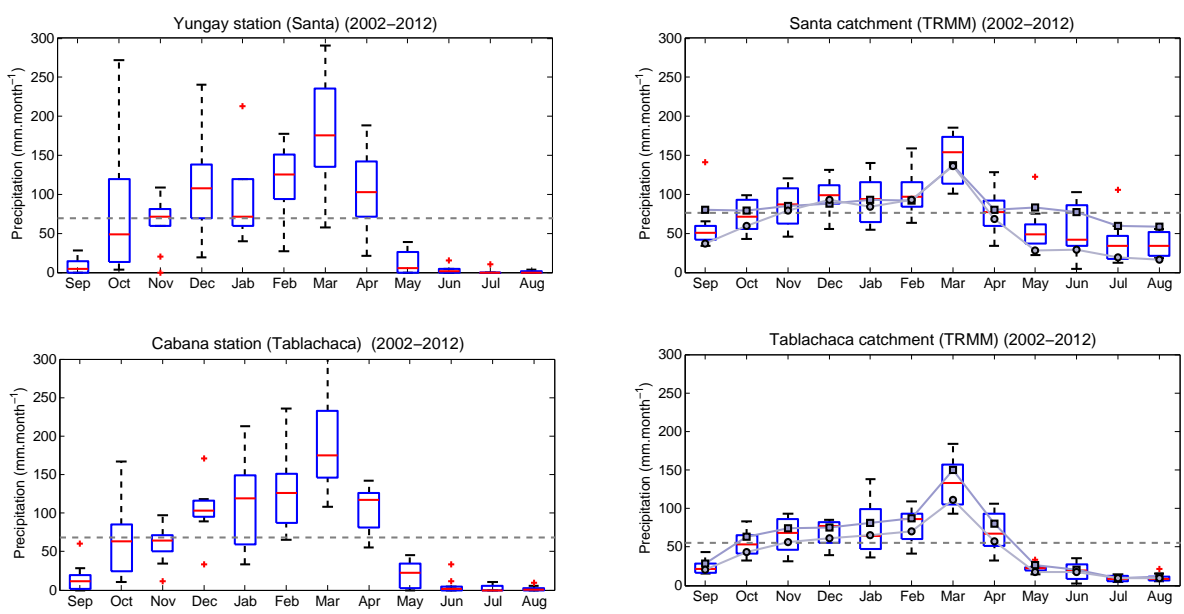

Fig. 4. Boxplots of mean monthly precipitation for 2002-2012 (red lines inside boxes) showing atypical events ("+") and 5th and 95th percentiles (ends of the dotted line). The horizontal dashed line is the monthly mean. On the left, observed precipitation based on daily values at Yungay and Cabana stations, representing Santa and Tablachaca sub-catchments, respectively. On the right, monthly TRMM (3B43 $7 \mathrm{~V}$ ) catchment precipitation in each $0.25^{\circ} \times 0.25^{\circ}$ grid. To capture spatial variability, filled squares were calculated from TRMM pixels above $3800 \mathrm{~m}$ a.s.1., while filled circles were calculated from TRMM stations below $3800 \mathrm{~m}$ a.s.1.

This second zone includes the semi-arid mountain range in the middle and upper basin, where variations in daily precipitation are more frequent and stronger during the afternoon and evening during the rainy season (Garreaud, 1999). On average, $90 \%$ of annual precipitation falls from October to April, with a peak in February and March (Fig. 4); consequently, streamflow dramatically increases $10-$ to 30 fold during the wet season. The rest of the year (MaySeptember) is rather dry, with less than $50-100 \mathrm{~mm}$ of precipitation (Vuille et al., 2008).

Surface runoff in the upper sub-catchment of the Santa River originates from rainfall and glacier snowmelt on the Cordillera Blanca (Mark and Seltzer, 2003). During the dry season, groundwater accounts for $18-74 \%$ of the water entering some catchments, with the rest coming from glacier meltwater (Baraer et al., 2009; Condom et al., 2012).

In mountain catchments, especially in developing countries, significant spatial and temporal gaps in ground-based climate records exist (Scheel et al., 2011). We obtained precipitation estimates from the TRMM Multi-satellite Precipitation Analysis (TMPA) level-3 product 3B43-7V (19982012, Fig. 4), from the Goddard Earth Sciences Data and Information Services Center product (http://mirador.gsfc.nasa. gov). TMPA is a combined from several (10) data providers (Huffman and Bolvin, 2013). This dataset is a calibrationbased sequential scheme for combining precipitation estimated from multiple satellites, as well as gauge analyses where feasible, to create a new monthly precipitation product on a $2.5^{\circ} \times 2.5^{\circ}$ grid (Huffman et al., 2007). The TMPA products were processed at catchment scale (Fig. 4) to estimate mean monthly precipitation on the two catchments and capture its spatial variability.
Two in situ rainfall stations with daily rainfall data, Yungay $\left(2537 \mathrm{~m}\right.$ a.s.l.; $\left.-9.14992^{\circ} \mathrm{S},-77.75103^{\circ} \mathrm{W}\right)$ for the Santa sub-catchment and Cabana (3300 m a.s.l.; $-8.3531^{\circ} \mathrm{S}$, $\left.-78.00201^{\circ} \mathrm{W}\right)$ for the Tablachaca sub-catchment, were used (Fig. 1). These precipitation data were recorded by the Peruvian Institute of Meteorology and Hydrology (SENAMHI). Spatial variability in monthly precipitation was evaluated with the TRMM dataset, considering two data subsets per sub-catchment: pixels representing areas $>3800 \mathrm{~m}$ vs. those of areas $<3800 \mathrm{~m}$.

For 2002-2012, mean annual precipitation was similar for each station $\left(\sim 850 \mathrm{~mm} \mathrm{yr}^{-1}\right.$; Fig. 4$)$, and each dataset correctly showed an October to April wet season and a May to September dry season. Comparison of monthly precipitation from each data subset showed no major differences $\left(<20 \mathrm{~mm} \mathrm{month}^{-1}\right)$. Cabana and Yungay stations were directly compared with the TRMM catchment precipitation datasets, suggesting that Cabana and Yungay data are representative of mean precipitation in Tablachaca and Santa sub-catchments, respectively. Consequently, the two time series were processed to calculate a probability density function (PDF, Fig. 6), according to Andronova and Schlesinger (2001) (see Sect. 3.2 for the analysis).

\section{Results}

\subsection{New dataset: outflow and sediment yield}

Accurate estimates of SSY depend on effective monitoring strategies (Duvert et al., 2011). This study uses an extensive database as one input to increase understanding of relations between SSY and environmental variables at the 


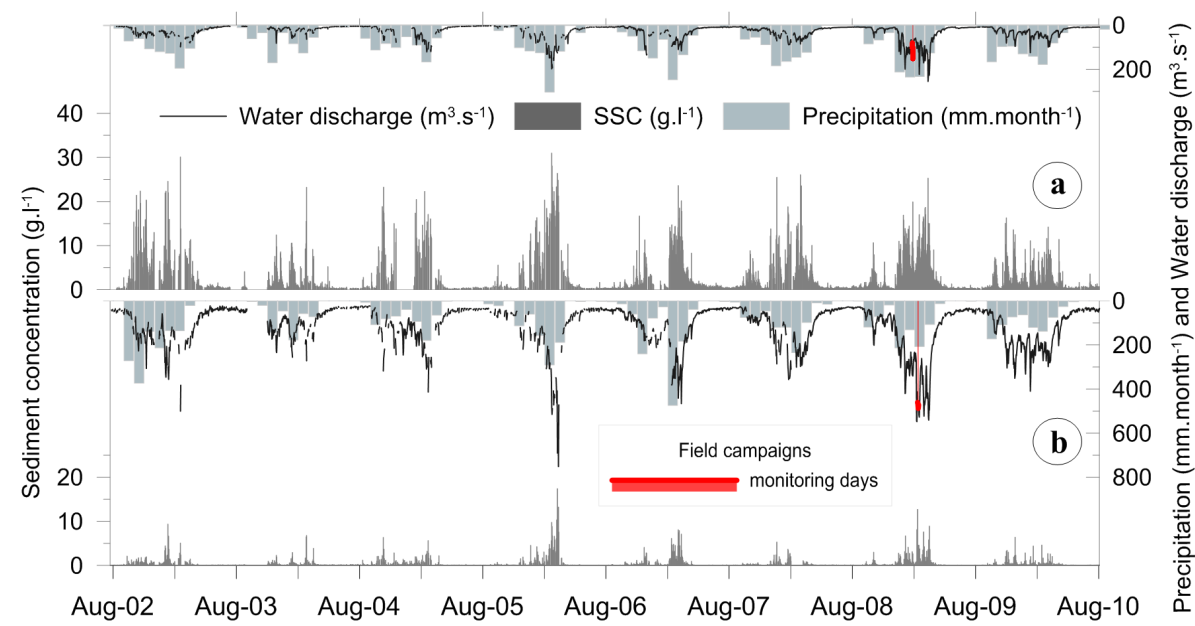

Fig. 5. Historic (9 yr) observed river discharge (top), precipitation and suspended sediment concentration (SSC). (a) Tablachaca station mean

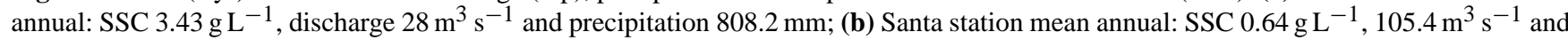
precipitation $810.4 \mathrm{~mm}$. Days of the field data collection are in red; see Table 2 for sample details.

catchment scale in the Andes. Since 1999, the Peruvian irrigation CHAVIMOCHIC project has been performing sediment flux monitoring. Daily water discharge $(Q)$ readings are taken by water-level recorder equipment, and are based on the relation between the gauging and level readings; a water discharge curve is generated. Samples of SSC are taken twice a day (06:00 and 18:00) at the Condorcerro, Santa and Tablachaca stations. As a result, an exceptional unpublished database is available with two SSC samples per day (Fig. 5) and instantaneous water-level recorder readings of $Q$.

Sample SSC measurements available at the gauging stations were evaluated considering an average resolution of one sample per day for each station. A lack of SSC data for a particular day did not necessarily constitute a "true" data gap. One can expect the use of a sediment rating curve (SSC vs. $Q$ ) to give plausible results in such cases, unless SSC is entirely unrelated to $Q$. Only if the flow record was also missing were data considered missing. After that, the percentage of available SSC data was calculated for each month. The entire observed dataset at Condorcerro station contained $2.5 \%$ SSC data gaps, $1.7 \%$ corresponding to the rainy season. The entire Tablachaca station dataset contained $26 \%$ SSC data gaps, $12.4 \%$ corresponding to the rainy season, while the entire Santa station dataset contained $35.4 \%$ SSC data gaps, $15.4 \%$ corresponding to the dry season. SSY data gaps in the Condorcerro station dataset were filled using the sediment rating curve equation (Fig. 7) $(n=11467$; $R>0.9 ; p<0.0001)$. Gaps in the Tablachaca and Santa SSY datasets were filled in two steps: (a) a balance in SSY between Condorcerro, Tablachaca and Santa stations (considering Condorcerro as a junction), as long as there was only one gap for the same interval of time in any station, and (b) averaging the SSY from the day before and the day after the day of the data gap. In the end, both Tablachaca and Santa stations had $19 \%$ data gaps in the treated dataset.
The annual hydrological cycle exhibits high seasonal contrast and permanent streamflow during the dry season in both sub-catchments due to glacier melt and groundwater contribution (Fig. 5). Daily $Q$ at the Tablachaca station had higher variability than that at the Santa station because of the former's smaller reception area and greater longitudinal river slope.

\subsection{Rainfall, $Q$, and SSC variability}

Mean daily $Q\left(\mathrm{~m}^{3} \mathrm{~s}^{-1}\right)$ from the Santa, Tablachaca and Condorcerro stations was estimated from instantaneous $Q$. Tablachaca and Santa stations had mean daily $Q$ of 28 and $105.4 \mathrm{~m}^{3} \mathrm{~s}^{-1}$, with standard deviations (SD) of 28.7 and $91.8 \mathrm{~m}^{3} \mathrm{~s}^{-1}$, respectively. These estimations make the Tablachaca River the major water discharge contributor along the Santa River. In terms of daily specific water discharge, Tablachaca and Santa stations showed an average of $0.009 \mathrm{~m}^{3} \mathrm{~km}^{-2} \mathrm{~s}^{-1}$ and $0.016 \mathrm{~m}^{3} \mathrm{~km}^{-2} \mathrm{~s}^{-1}$, with SD of 0.008 and 0.012 , respectively.

Frequency distribution analyses are useful to describe the distribution of $Q$ (Turcotte and Greene, 1993), floods (Malamuda and Turcotte, 2006), hazardous events (Korup and Clague, 2009) and sediment fluxes (Hovius et al., 2000; Lague et al., 2005) in natural systems. Frequency distribution analysis provides information on whether the probability of one event follows a specific trend, which expresses how natural systems control variables such as rainfall intensity, river $Q$ or SSC. Frequency distributions are more interesting, as they follow an analytic probability density function model because the probabilities of the occurrence and weight of a specific magnitude event can be derived mathematically. Therefore, frequency distributions are powerful criteria for comparing hydrological responses. In this study, we focus on the daily rainfall, $Q$ and SSC of the Tablachaca and 

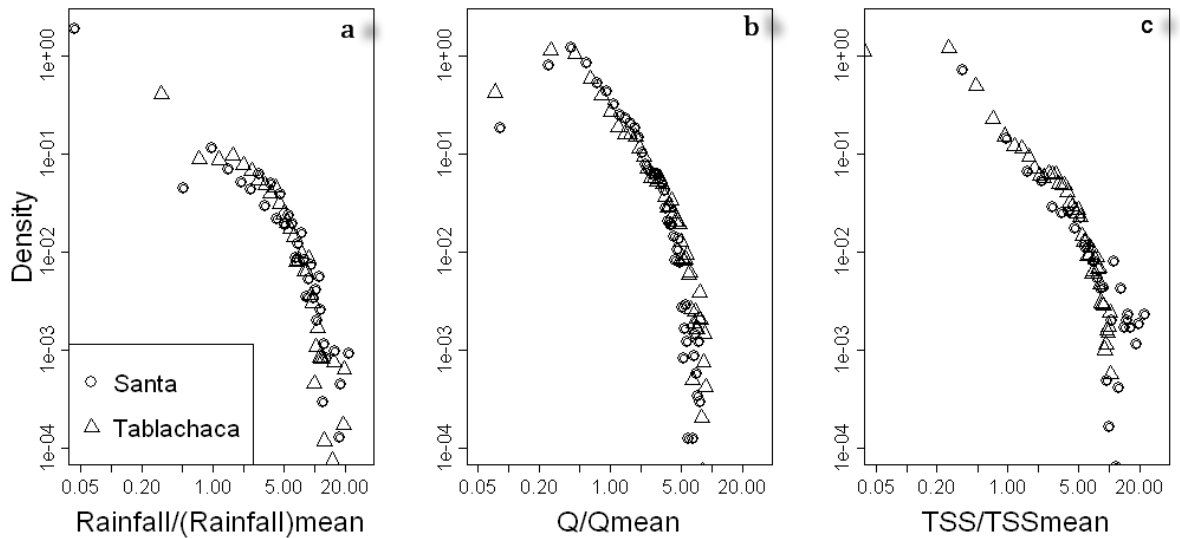

Fig. 6. Normalised probability density functions for the Santa and Tablachaca study catchments based on precipitation (a), water discharge $(Q)(\mathbf{b})$ and total suspended sediment (TSS) concentration (c).

Santa sub-catchments without carrying out detailed analyses. Comparison of magnitude-frequency distributions indicates whether or not the variables (rainfall, $Q$ and SSC) of both basins follow the same statistical trends. Note that a proper PDF comparison requires normalisation by the mean of the variable in each sample (Fig. 6).

PDFs of daily rainfalls and discharges have similar trends for both the Santa and Tablachaca sub-catchments (Fig. 6a and b) despite having different annual total water yield (486 and $282 \mathrm{~mm}$, respectively). This indicates that both catchments have a similar hydrological response. They differ only by the amplitude of the $Q$ s, which are relative to the drainage area and rainfall rate of each sub-catchment. However, the sub-catchment SSC PDFs differ significantly at concentrations larger than their respective means. SSC PDFs for the Santa and Tablachaca sub-catchments follow a monotonic decreasing power law and non-monotonic trends, respectively, which indicates different erosion and sediment transport responses to identical hydrological inputs (Fig. 6c). The sediment rating curve from 2002 to 2010 for the Santa and Tablachaca stations have a significant $R>0.9$ ( $p<0.0001$ ) (Fig. 7). The rating curves between specific $Q$ and SSC $\left([\mathrm{SSC}]=a Q^{b}\right)$ highlight this difference between sub-catchments (Fig. 7). The power-law exponents of the rating curves are similar (i.e. $b=1.8 \pm 0.1$ ) considering uncertainties between each one. This means that the response to hydrological inputs is identical in both catchments and does not vary much during the hydrological cycle. The coefficient $a$ marks the main difference in erosive output and suggests that the Santa and Tablachaca sub-catchments have different sediment availability. For an equivalent specific $Q$ the SSC of the Tablachaca River is on average nine times larger than that of the Santa River. Note that the Tablachaca's rating curve shows a rather stable and high SSC value $\left(\sim 350 \mathrm{mg} \mathrm{L}^{-1}\right)$ for specific discharges below a threshold value of $3 \times 10^{-3} \mathrm{~m}^{3} \mathrm{~km}^{-2} \mathrm{~s}^{-1}$. During the low-water season, when most of the sub-catchment experiences dry climate conditions, the SSC of the Tablachaca River varies from 150 to $3000 \mathrm{mg} \mathrm{L}^{-1}$, and in the field it is possible to see different water colours at stream confluences (Fig. 3). This indicates a large source of sediment in the channel that does not depend on $Q$. Also note that for large $Q$ s in the Tablachaca River during the rainy season, SSC fluctuates more around the rating curve, indicating that hydrological control of sediment production (in Tablachaca River) fluctuates more than in the Santa sub-catchment.

\subsection{Field monitoring}

During the rainy season (Febrary and March 2009), two field campaigns were performed on the Santa and Tablachaca subcatchments to collect water samples on several reaches of both river networks (Fig. 5). To track SSC sources with a high spatial resolution, all reaches of the Santa and Tablachaca rivers were sampled (Fig. 2 and Table 2). Monitoring of discharge on 53 sites revealed three spatial characteristics: glacier, middle and lower catchments. The glacier catchment refers to sampling sites whose associated streamflow comes most from glaciers, while middle and lower catchments are associated with steep slopes. Samples $(650 \mathrm{~mL})$ were manually collected at the edge of channel cross-sections, upstream and downstream of river confluences because of the rugged topography. This method is useful because of the turbulent flow at each sampling station. All samples were filtered using suction or gravity pumps through individually pre-weighed Whitman papers, and the quantity of sediment retained was determined gravimetrically.

\subsection{Slope, lithology and land-use analysis}

The percentage of catchment area within each slope degree was calculated using GIS (also Fig. 8). Slopes range from 0 to $60^{\circ}$, and both catchments have the same frequency distribution of slope. The study area shows a wide range of slopes distributed from the hillfronts to piedmont and arid surfaces, 


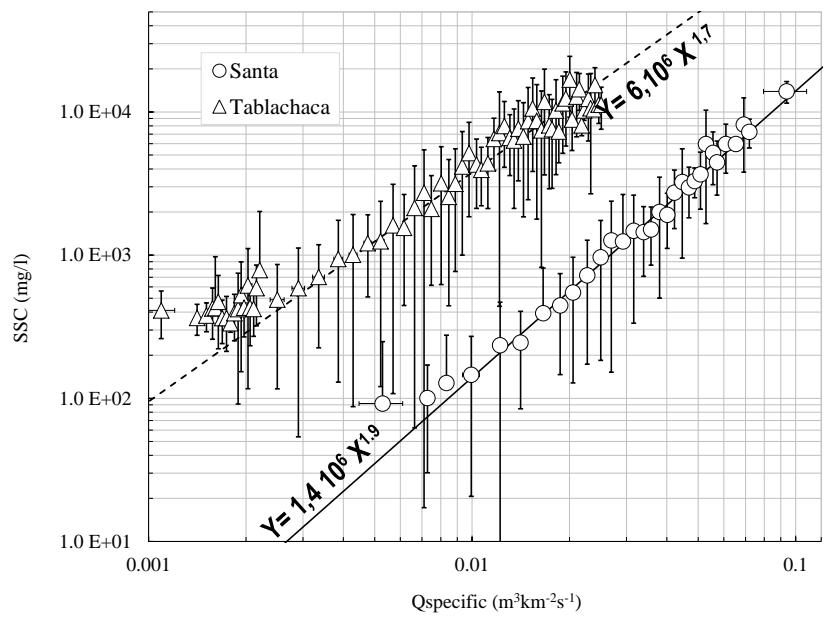

Fig. 7. Log-log relation of suspended sediment concentration (SSC, $\left.\mathrm{mg} \mathrm{L}^{-1}\right)$ and corresponding specific water discharge $\left(Q_{\mathrm{S}}\right)$ $\left(\mathrm{m}^{3} \mathrm{~km}^{-2} \mathrm{~s}^{-1}\right)$ at the Tablachaca and Santa stations. Solid and dashed lines are the power-law best fit for all data collected in the Santa and Tablachaca rivers, respectively. Bars represent the monthly variations.

and all this over different lithologies. The Tablachaca subcatchment has a larger surface, with slopes between $7^{\circ}$ and $25^{\circ}$, than the Santa sub-catchment (Fig. 8). However, the Santa catchment has more surfaces with slopes $<7^{\circ}$ and $>25^{\circ}$. These differences in slope distribution are not large enough to explain the observed difference in erosion rates.

Particular differences between arable land and other land uses will also affect soil erosion and hence SSY (Montgomery, 2007; Vanacker et al., 2005). The total areas of the Tablachaca and Santa sub-catchments were composed of, respectively, $4 \%$ and $8 \%$ dispersed open-pit mining activity, $1 \%$ and $7 \%$ glacier remains, $39 \%$ and $32 \%$ woodland areas, $48 \%$ and $46 \%$ scraggly and seasonal vegetation cover (bare soil), and $9 \%$ and $7 \%$ urban cover. Thus, the dominant land uses in the Tablachaca and Santa sub-catchments are bare soil and woodland (Fig. 9). This analysis, based on six types of land cover, showed no major difference in the spatial distribution of land uses between the Santa and Tablachaca sub-catchments.

The Tablachaca and Santa sub-catchments showed differences, however, in the spatial distribution of lithologies (Table 1, Fig. 2). Surface areas of Chimu (code 2a), Calipuy (code 3) and Chicama (code 1a) formations were 5, 2.1 and 1.5 times higher in the Tablachaca sub-catchment than in the Santa sub-catchment, respectively. Conversely, areas of granodiorite (code 5) and fluvio-glacial formations (6b) were 5 and 14 times higher in the Santa sub-catchment than in the Tablachaca sub-catchment, respectively. Besides the fluvio-glacial formation, one of the least cohesive lithologies in both sub-catchments, it is difficult to properly quantify the relative cohesiveness of each formation. Therefore, the relative surface area of each lithology cannot be specifically

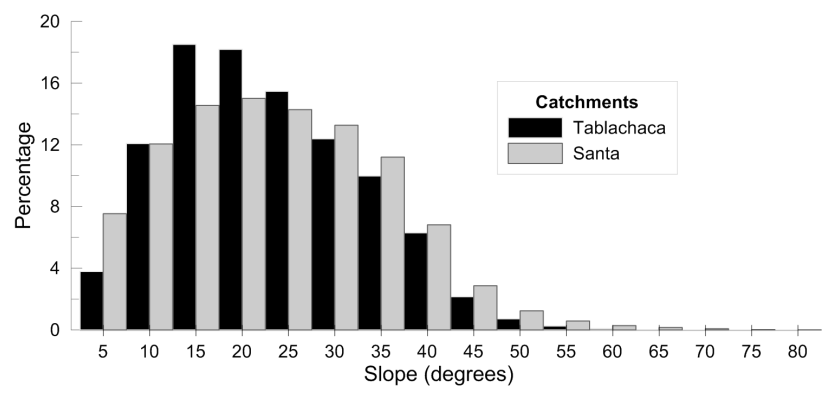

Fig. 8. Histogram of the normalised percentage distribution of slopes generated from the $90 \mathrm{~m}$-resolution digital elevation model (DEM) in the Santa and Tablachaca study catchments.

balanced with a simple coefficient of cohesiveness specifically for the sub-catchments where mining activities are well developed.

Slope distribution of the two main land-use types (i.e. woodland and bare soil) differs only for bare soils in the Santa sub-catchment, which have a higher percentage of the steepest slopes (Fig. 9). In contrast, lithology formations in the Tablachaca sub-catchment do not have steeper slopes than those in the Santa sub-catchment (Fig. 10). Assuming that erosion rates increase with steeper slopes, weighting land-use surface areas with slope distribution does not explain the difference in erosion rates between the two subcatchments. Slope distribution as a function of lithology shows that the Tablachaca sub-catchment has a much larger area of Mesozoic-Chimu coal (Code 2a; $342 \mathrm{~km}^{2}$ ) than the Santa sub-catchment $\left(71 \mathrm{~km}^{2}\right)$. Its heavy mining is in accordance with the much higher SSY observed in the former.

\subsection{Suspended sediment concentration monitoring}

During the field campaign (February and March 2009) in the Santa sub-catchment, two main regions of differing SSC were distinguished. At higher elevations of the subcatchment, SSC in water discharges, which comes from a glaciated area, ranged from 7.2 to $120 \mathrm{mg} \mathrm{L}^{-1}$, while at lower elevations higher concentrations were observed (123$2682 \mathrm{mg} \mathrm{L}^{-1}$; Table 2 and Fig. 2). For the Tablachaca subcatchment, SSC was low at higher elevations (points 45, 46, 48 in Fig. 2); however, in the area of the Chimu Formation (code 2a), SSC remained high, ranging from 4970 to $24472 \mathrm{mg} \mathrm{L}^{-1}$ (point 50 in Fig. 2). In contrast, SSC remained low in the lower catchment, ranging from 429 to $850 \mathrm{mg} \mathrm{L}^{-1}$ (points 48 and 49 in Fig. 2), and most values came from a mixed lithology (Fig. 2; codes 1a, 1b, 3 and 5).

Overall mean values for the Tablachaca and Santa sub-catchments during field monitoring were 10858 and $444 \mathrm{mg} \mathrm{L}^{-1}$, respectively (standard deviation $=9435$ and $402 \mathrm{mg} \mathrm{L}^{-1}$, respectively). These monitoring results demonstrate a markedly high spatial contrast in SSC in the Tablachaca catchment and also between the Tablachaca and Santa catchments. 

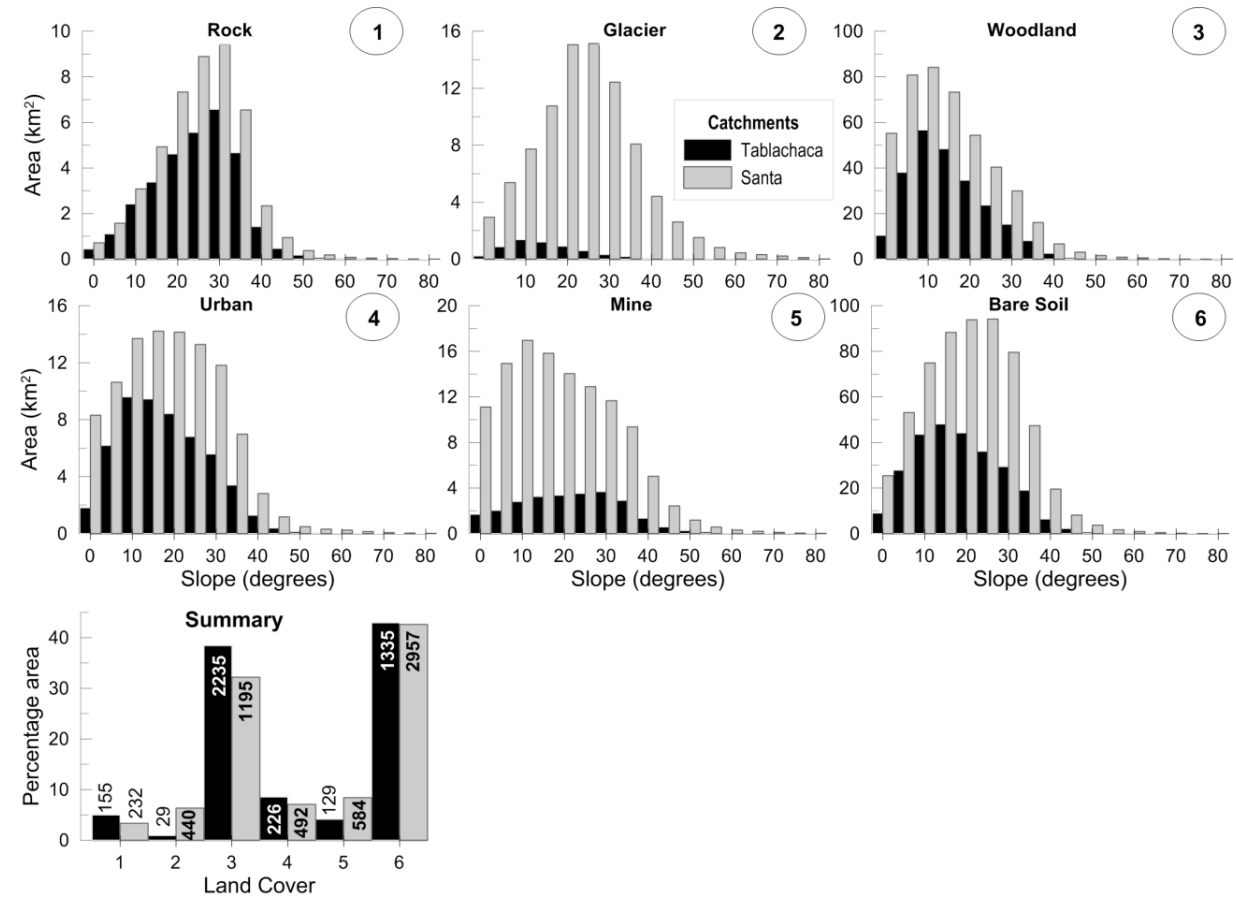

Fig. 9. Slope distribution as a function of land use in the Tablachaca and Santa study catchments. Values in the bars of the graph at bottom left gives the area in $\mathrm{km}^{2}$ for each land use.

\section{Discussion}

\subsection{Suspended load/bedload partitioning}

In this study, all measurements and analysis focused on suspended load because of the lack of any data about bedload. Our results for SSY are therefore underestimations of the total sediment yield. Following the review of Turowski et al. (2010), there is no relevant empirical law to define this partitioning from watershed characteristics. Currently the percentage of bedload in total sediment yield varies from 0 to $100 \%$ according to the river context. For Andean catchments similar to the Santa and Tablachaca catchments, there are no published data about bedload yield. More to the north of Peru, in the Catamayo-Chira catchment, total sediment yield has been quantified with bathymetric monitoring of the Poechos reservoir (Tote et al., 2011). Unfortunately, these data cannot be compared to ours because the climate of the Catamayo-Chira catchment is impacted more by El Niño and La Niña events than that of the Santa and Tablachaca catchments, and because differences in the SSY vs. $Q$ rating curves between these catchments reveal different sediment production and transport processes.

Currently, there is bedload transport in the Santa and Tablachaca rivers, based on the metric size of bed sediments at many places in their river networks. Bedload estimation is therefore an important step in quantifying the total balance of the sediment yield. In our study, all measures, results and discussions focus on the portion that is suspended sediment to highlight interesting significant erosion rates and spatial contrasts.

\subsection{SSC control factors}

One of the main results of this study is the large difference in SSY between Tablachaca and Santa sub-catchments. The SSY of the Tablachaca sub-catchment is four times larger than that of the Santa sub-catchment despite the former having relatively higher mean annual rainfall, water discharge and slopes. Better understanding of this difference in erosion rates required a fine analysis of plausible erosion factors. Using a variety of datasets and methods, we analysed correlations between criteria, empirical relations and spatial distribution of rainfall rates, daily water discharges, SSC, slope frequencies, lithology, and land uses. Combining these results led to the following interpretation.

The rating curves for the Tablachaca and Santa rivers are well defined, and the sensitivity of SSC to $Q$, represented by the exponent $b$ of the rating curve, is the same for both catchments (Fig. 7). Water discharge variability undoubtedly controls sediment yield above a threshold value, with the same dynamics in both sub-catchments, and explains why sediment-transport processes look similar at the Santa and Tablachaca sub-catchment scale. But the sediment available for transport through the river network, represented by the coefficient $a$, is at least four times larger in the Tablachaca sub-catchment. Note that below the threshold 

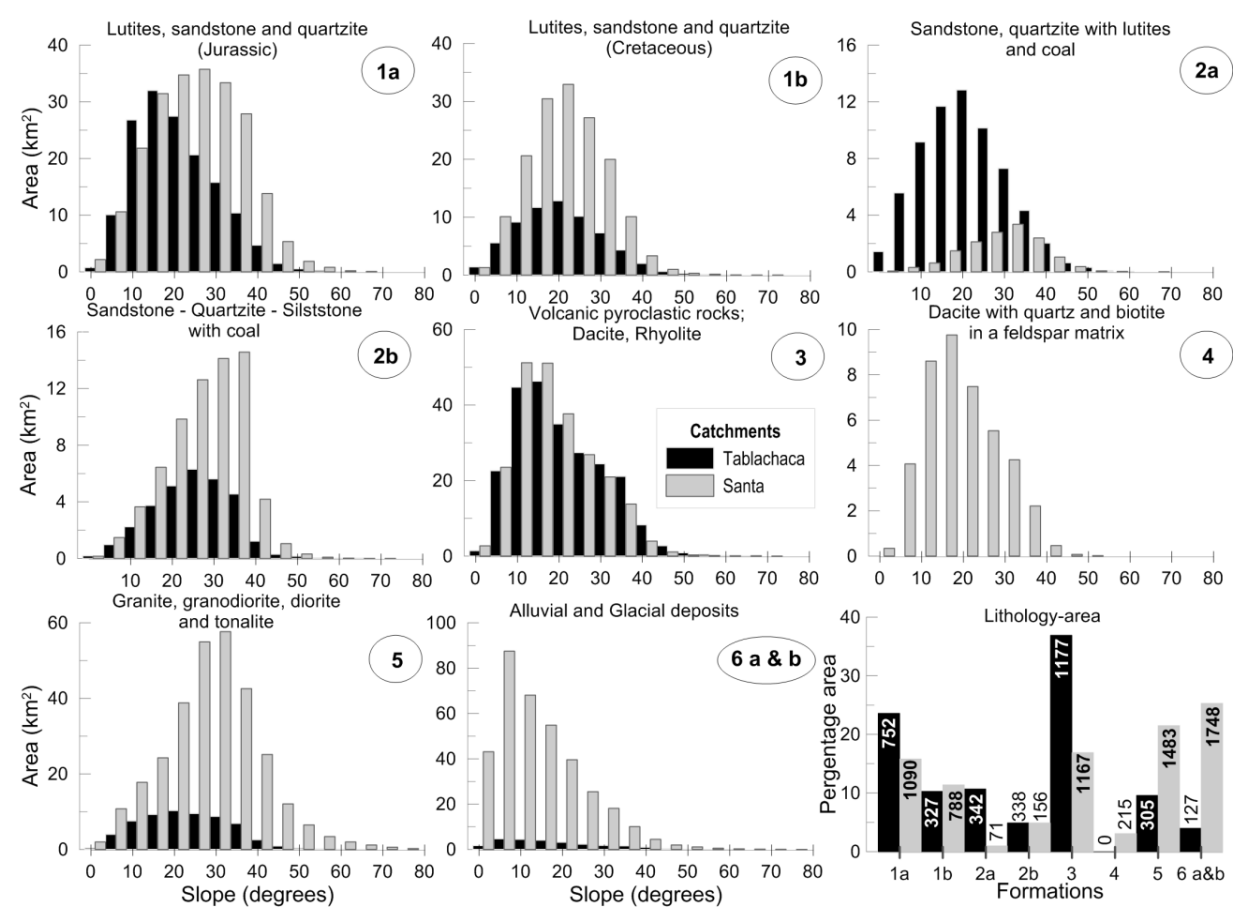

Fig. 10. Slope distribution as a function of lithology formation in the Tablachaca and Santa study catchments. Values in the bars of the graph at bottom right give the area in $\mathrm{km}^{2}$ for each formation.

of water discharge, there is evidence of a sediment source that induces high SSC in the Tablachaca River during the dry season regardless of variability in water discharge. This may be induced by artisanal gold exploration in the Tablachaca River bed, which occurs during the dry season. Since these mining activities stop during the rainy season due to limited access to the river bed, they cannot explain the gap in sediment availability over the range of specific discharge values.

Spatial distribution of SSC over the Santa and Tablachaca drainage areas during the field campaign period shows how SSC is locally controlled. These catchments do not show similar SSC spatial variability. Along the Santa network, SSC varies between 7 and $2682 \mathrm{mg} \mathrm{L}^{-1}$, with a mean and standard deviation of 444 and 402, respectively. Along the Tablachaca network, there are larger variations in SSC between adjacent sub-catchments of similar size $\left(\sim 100 \mathrm{~km}^{2}\right)$ within a range of $43-24472 \mathrm{mg} \mathrm{L}^{-1}$, with a mean and standard deviation of 10858 and 9435, respectively. Considering the relatively homogeneous spatial distribution of rainfall during the field campaign, such spatial distribution of SSC does not correspond to natural spatial variability of sediment production but is rather correlated with the location of intensive mining activities and lithologic domains in upstream portions of the Tablachaca sub-catchment. No specific hydrologic conditions during the field campaign can explain the high SSC values observed on a few upstream segments of the Tablachaca network. SSC decreases downstream due to less concentrated inputs in downstream reaches but remains relatively high until the confluence with the Santa River, with a value of $13.3 \mathrm{mg} \mathrm{L}^{-1}$. This SSC dataset highlights the coupled impact of mining and lithology on SSC and explains the high values found for the Tablachaca River.

The mineral composition of the highest suspended sediment concentration was measured in the X-ray laboratories of the Geological, Mining and Metallurgical Institute (INGEMMET). Results show that it is composed of orthoquartzites, siltstones, sandstones, shales and coal and matches mainly the Chimu Formation (code 2a) (CarrascalMiranda and Suárez-Ruiz, 2004). Chimu lithology, covering $11 \%$ and $1 \%$ of the Tablachaca and Santa sub-catchment areas, respectively, represents the main lithologic difference between these sub-catchments. Furthermore, the highest incidence of mining is observed on Chimu (code 2a) lithology in the Tablachaca sub-catchment.

Because the rainfall, hydrology, land-use and slope data cannot explain the differences in erodibility, and because SSC spatial distribution is well correlated with lithology and mining activities, the former emerge as the main control factors to explain this difference. The unusually high SSC observed at the outlet of the Tablachaca River for a wide range of specific water discharge values shows that large amount of sediment is available on the Tablachaca's hillslopes and river bed. Indeed, soft material coming from landslides, continuous delivery of fresh mine tailings and exploitation of river bed material can be seen at many places on both channel networks. 
Table 3. Overview of the average to the highest amount of sediment production coming from the Andes mountains; each monitoring location is shown in Fig. 1. Santa (32), Tablachaca (33) and Condorcerro (34) rivers are the dark shaded points.

\begin{tabular}{|c|c|c|c|c|c|c|c|c|}
\hline Code & Catchment & $\begin{array}{l}\text { Catchment } \\
\text { Area }\left(\mathrm{km}^{2}\right)\end{array}$ & $\begin{array}{r}\text { Annual mean } \\
\text { discharge } \\
\left(\mathrm{m}^{3} \mathrm{~s}^{-1}\right)\end{array}$ & $\begin{array}{r}\text { Sediment Yield } \\
\left(\mathrm{t} \mathrm{km}^{-2} \mathrm{yr}^{-1}\right)\end{array}$ & Ocean & Period & Country & Source \\
\hline 1 & Magdalena-Calamar & 257440 & 7200 & 560 & Atlantic & 1975-2005 & Colombia & Pépin (2007) \\
\hline 3 & Coca & 5330 & 480 & 919 & Atlantic & 2001-2005 & Ecuador & Laraque et al. (2009) \\
\hline 4 & Napo FDO & 12400 & 1200 & 516 & Atlantic & 2001-2005 & Ecuador & Laraque et al. (2009) \\
\hline 5 & Napo & 100520 & 1486 & 1577 & Atlantic & 2001-2005 & Ecuador & Laraque et al. (2009) \\
\hline 8 & Ucayali-Atalaya & 190810 & 6540 & 1955 & Atlantic & 2009-2010 & Peru & Armijos et al. (2013) \\
\hline 9 & Béni-Rurrenabaque & 68900 & 1960 & 2293 & Atlantic & 2003-2010 & Bolivia & Pépin et al. (2013) \\
\hline 10 & Grande-Abapo & 62000 & 230 & 2581 & Atlantic & 2003-2007 & Bolivia & Pépin et al. (2013) \\
\hline 11 & Negro & 4604 & 136 & 1730 & Caribbean & 2004-2010 & Colombia & Restrepo et al. (2006a) \\
\hline 12 & Carare & 4943 & 90 & 2200 & Caribbean & 1985-1998 & Colombia & Restrepo et al. (2006a) \\
\hline 13 & Saldaña & 7009 & 320 & 1271 & Caribbean & 1974-1999 & Colombia & Restrepo et al. (2006a) \\
\hline 19 & Cabrera & 2446 & 71 & 755 & Caribbean & 1982-1998 & Colombia & Restrepo et al. (2006a) \\
\hline 20 & Cocorna & 799 & 56 & 745 & Caribbean & 1978-1999 & Colombia & Restrepo et al. (2006a) \\
\hline 21 & Samana & 1490 & 181 & 625 & Caribbean & 1983-1999 & Colombia & Restrepo et al. (2006a) \\
\hline 22 & Yaguara & 1386 & 15 & 593 & Caribbean & 1983-1999 & Colombia & Restrepo et al. (2006a) \\
\hline 23 & Nus & 320 & 17 & 582 & Caribbean & 1983-1995 & Colombia & Restrepo et al. (2006a) \\
\hline 24 & Ceibas & 220 & 5 & 581 & Caribbean & 1983-1999 & Colombia & Restrepo et al. (2006a) \\
\hline 25 & Maipo & 370 & 16 & 1782 & Pacific & 1985-2006 & Chile & Pépin et al. (2010) \\
\hline 26 & Aconcagua & 135 & 48 & 1356 & Pacific & 1966-1989 & Chile & Pépin et al. (2010) \\
\hline 27 & Tado & 1600 & 261 & 1570 & Pacific & 1986-1994 & Colombia & Restrepo et al. (2004) \\
\hline 28 & Pte Guascas & 8900 & 225 & 1714 & Pacific & 1972-1993 & Colombia & Restrepo et al. (2004) \\
\hline 29 & San Juan & 14000 & 2600 & 1150 & Pacific & 1970-1996 & Colombia & Restrepo et al. (2006b) \\
\hline 30 & Patia & 14000 & 317 & 972 & Pacific & 1972-1993 & Colombia & Restrepo et al. (2006b) \\
\hline 31 & Chira & 20000 & 159 & 1000 & Pacific & - & Peru & Restrepo et al. (2006b) \\
\hline
\end{tabular}

\subsection{Specific suspended sediment yield vs. runoff in the Andes}

Although the Tablachaca and Santa sub-catchments are geographically close to each other, their SSY standard deviations showed two different SSY ratios. The estimated mean annual SSY for the Tablachaca sub-catchment is $2204 \pm 337 \mathrm{t} \mathrm{km}^{2} \mathrm{yr}^{-1}$, which is three times greater than that for the Santa sub-catchment $\left(779 \pm 162 \mathrm{t} \mathrm{km}^{2} \mathrm{yr}^{-1}\right)$ (Table 3) despite the fact that the streamflow of the Santa River is four times greater than that of the Tablachaca sub-catchment. It should be noted that the study period did not include mega El Niño events, during which the highest SSY and discharges are expected.

To summarise, the SSY at the outlet of the Tablachaca subcatchment represents one of the highest erosion rates in the entire Andes, even though the values measured in this study exclude bedload fluxes, which still need to be estimated.
Strong, unexplained spatial differences in SSY could lead to misinterpreting analysis of erosion-control factors at a global scale. We illustrate this point by compiling SSY vs. runoff data from the central and northern Andes from previous studies (Figs. 11 and 12). From this dataset there is no evidence of runoff controlling SSY since there is no clear relation between them, and the highest SSY are found in the most arid regions. There is no doubt, however, that runoff is one of the main factors controlling SSY. This is because water discharge is intrinsically related to river water velocity (i.e. the main factor causing mechanical shear stress and sediment transport) and because rating curves between SSC and Q in many of these Andean catchments are statistically significant despite data dispersion.

This study shows that analysis of the dependency of SSY on runoff at a global scale should be carefully performed to filter other significant control factors. Mean annual runoff values are not relevant for establishing an empirical relationship between runoff and SSY at a regional scale. Both daily 


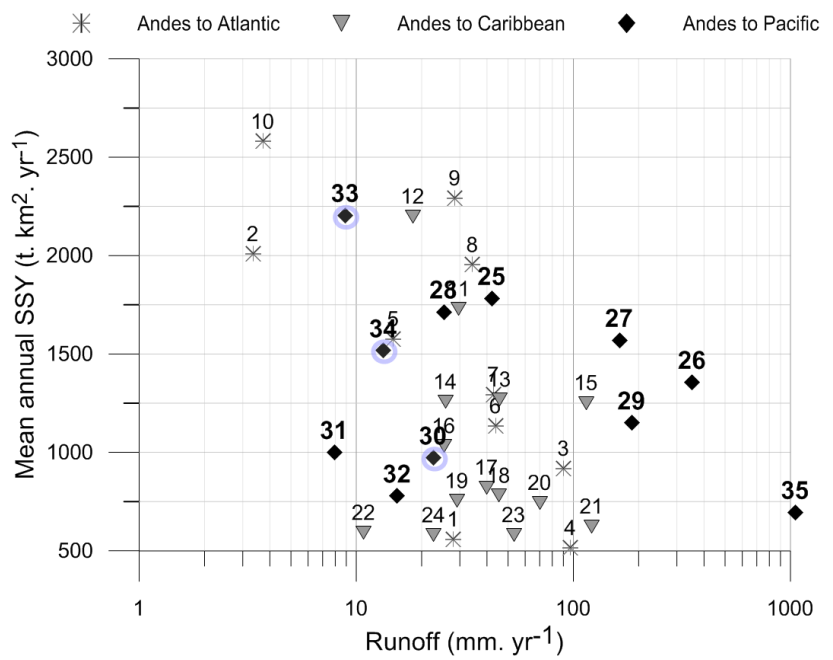

Fig. 11. Relations between suspended sediment yield (SSY) from various sources (see Table 3) and runoff for several mountain rivers in the South American Andes. The Santa (32), Tablachaca (33) and Condorcerro (34) rivers, from this study, are circled.

water discharge distribution and physical processes related to rating curve parameters control annual SSY. The intercept and potential thresholds of the rating curve represent the dependency of SSY on factors, which is not relative to runoff and could be specific to each catchment. Any empirical analysis of dependency of SSY on factors should clearly consider the distinction between those parameters. Therefore, using annual mean values for runoff and SSY mixes dependency on different factors and can lead to erroneous interpretations.

Furthermore, this study emphasises how SSY at the $10000 \mathrm{~km}^{2}$ scale can be controlled by local processes such as mines on a small percentage of the drainage area with specific lithology domains. If locally efficient erosive processes are suspected, such as in the western Andes, where mines are densely aggregated, analysis of erosion-control factors must be done with high temporal and spatial resolution data to understand SSY datasets better.

\section{Conclusions}

In Peru, hydro-sedimentology information is limited and scarce. This study provides an important contribution to quantify SSY in two adjacent central Andean subcatchments, the Santa and Tablachaca, which drain a large part of the Cordillera Blanca. Despite their hydro-climatic and geomorphic similarities, the Santa and Tablachaca sub-catchments have mean annual SSY equal to 779 and $2204 \mathrm{t} \mathrm{km}^{2} \mathrm{yr}^{-1}$, respectively. Indeed, the latter is one of the larger annual SSY in the entire western Andes. Mining activities within a specific lithology on the Tablachaca subcatchment can explain the differences in SSY.

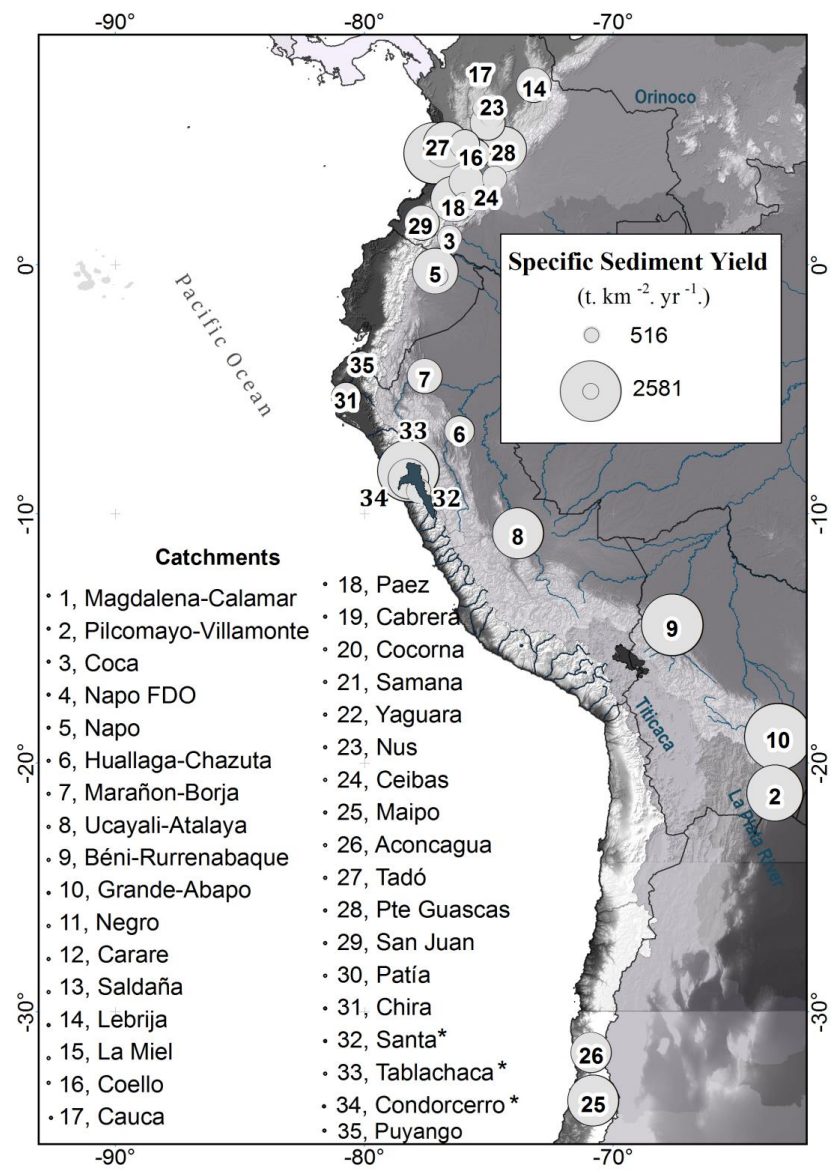

Fig. 12. The largest volumes of sediment delivered from the northern, central and southern cordillera of the Andes mountains. Circle size corresponds to sediment yields. Numbers on the map correspond to data sources in Table 3. Asterisks $\left(^{*}\right)$ denote study catchments.

These results show that analysis of control factors of regional SSY at the Andes scale should be done carefully. Analysis based on mean annual values of relevant variables can lead to misinterpretations about erosion-control factors. Logically, the pertinent scale for building databases is related to the main spatial and temporal heterogeneities of erosion-process rates. In the west-central Andes, where mining in specific lithologies is highly heterogeneous, spatial data at the $\mathrm{km}$ scale and daily water discharge and SSC data are necessary to define the main erosion factors throughout the range.

Acknowledgements. This work was initiated as part of a Ph.D. dissertation at La Molina Agrarian National University; it is financially supported by a doctoral research scholarship from the Science and Technology Programme (FYNCYT, www.fincyt.gob.pe). The authors are grateful for the funding through GREAT ICE team and the HYBAM observatory (www.ore-hybam.org), a join FrenchPeruvian program, associating the French Institut de Recherche 
pour le Développement (IRD, www.ird.fr), the SENAMHI (www.senamhi.gob.pe) and the UNALM (www.lamolina.edu.pe). We also give special thanks to the CHAVIMOCHIC project, which kindly provided the river discharge and SSC data. We also thank Julien Nemery and four anonymous reviewers for valuable support and fruitful discussions that helped to increase the quality of the manuscript.

Edited by: W. Buytaert

\section{References}

Aalto, R., Dunne, T., and Guyot, J. L.: Geomorphic controls on Andean denudation rates, J. Geol., 114, 85-99, doi:10.1086/498101, 2006.

Adams, J. B., Sabol, D. E., Kapos, V., Filho, R. A., Roberts, D. A., and Smith, M. O.: Classification of multispectral images based on fractions of endmembers: application to land-cover change in the Brazilian Amazon, Remote Sens. Environ., 52, 137-154, 1995.

Agramonte, J. and Diaz, A.: Inventario preliminar del carbon mineral en el Peru, Instituto Geologico Minero y Metalurgico, Lima, Peru, 77, 1983.

Andronova, N. G. and Schlesinger, M. E.: Objective estimation of the probability density function for climate sensitivity, J. Geophys. Res., 106, 22605-22611, doi:10.1029/2000JD000259, 2001.

Armijos, E., Crave, A., Vauchel, P., Fraizy, P., Santini, W., Moquet, J., Arevalo, N., Carranza, J., and Guyot, J. L.: Suspended sediment dynamics in the Amazon River of Peru, J. S. Am. Earth Sci., 44, 75-84, doi:10.1016/j.jsames.2012.09.002, 2013.

Baraer, M., McKenzie, J. M., Mark, B. G., Bury, J., and Knox, S.: Characterizing contributions of glacier melt and groundwater during the dry season in a poorly gauged catchment of the Cordillera Blanca (Peru), Adv. Geosci., 22, 41-49, doi:10.5194/adgeo-22-41-2009, 2009.

BCRP: Economic Synthesis for Ancash, Central Bank of Peru, Lima, Peru, 2009.

Carrascal-Miranda, E. and Suárez-Ruiz, I.: Short description of the Peruvian coal basins, Int. J. Coal Geol., 58, 107-117, doi:10.1016/j.coal.2003.05.004, 2004.

Condom, T., Escobar, M., Purkey, D., Pouget, J. C., Suarez, W., Ramos, C., Apaestegui, J., Tacsi, A., and Gomez, J.: Simulating the implications of glaciers' retreat for water management: a case study in the Rio Santa basin, Peru, Water Int., 37, 442-459, doi:10.1080/02508060.2012.706773, 2012.

Duvert, C., Gratiot, N., Némery, J., Burgos, A., and Navratil, O.: Sub-daily variability of suspended sediment fluxes in small mountainous catchments - implications for communitybased river monitoring, Hydrol. Earth Syst. Sci., 15, 703-713, doi:10.5194/hess-15-703-2011, 2011.

Ericksen, E. G., Plafker, G., and Concha, F. J.: Preliminary Report on the Geologic Events Associated With the 31 May, 1970, Peru Earthquake, USGS, Washington, 1-25, 1970.

Garreaud, R.: Multiscale Analysis of the Summertime Precipitation over the Central Andes, Month. Weather Rev., 127, 901-921, doi:10.1175/1520-0493(1999)127<0901:MAOTSP>2.0.CO;2, 1999.
Garreaud, R. D.: The Andes climate and weather, Adv. Geosci., 22 , 3-11, doi:10.5194/adgeo-22-3-2009, 2009.

Garreaud, R. and Fuenzalida, H.: The Influence of the Andes on Cutoff Lows: A Modeling Study, Month. Weather Rev., 135, 1596-1613, doi:10.1175/MWR3350.1, 2007.

Garreaud, R. and Rutllant, J.: Análisis meteorológico del los aluviones de Antofagasta y Santiago de Chile en el periodo 19911993, Atmósfera, 9, 251-271, 1996.

Georges, C.: The 20th-Century Glacier Fluctuations in the Tropical Cordillera Blanca (Peru), Arct. Antarct. Alp. Res., 36, 100-107, 2004.

Giovanni, M., Horton, B., Garzione, C., McNulty, B., and Grove, M.: Extensional basin evolution in the Cordillera Blanca, Peru: Stratigraphic and isotopic records of detachment faulting and orogenic collapse in the Andean hinterland, Tectonics, 29, 1-21, doi:10.1029/2010TC002666, 2010.

Göttlicher, D., Obregón, A., Homeier, J., Rollenbeck, R., Nauss, T., and Bendix, J.: Land-cover classification in the Andes of southern Ecuador using Landsat ETM+ data as a basis for SVAT modelling, Int. J. Remote Sens., 30, 1867-1886, doi:10.1080/01431160802541531, 2009.

Guyot, J. L.: Hydrogéochimie des fleuves de l'Amazonie bolivienne, ORSTOM, Paris, France, 261 pp., 1993.

Harden, C.: Human impacts on headwater fluvial systems in the northern and central Andes, Geomorphology, 79, 249-263, doi:10.1016/j.geomorph.2006.06.021, 2006.

Hovius, N., Stark, C. P., Chu, H.-T., and Lin, J.-C.: Supply and removal of sediment in a landslide-dominated mountain belt: Central Range, Taiwan, Geology, 108, 73-89, 2000.

Huffman, G. J. and Bolvin, D. T.: TRMM and other data precipitation data set documentation, NASA, Greenbelt, USA, 1-40, 2013.

Huffman, G. J., Bolvin, D. T., Nelkin, E. J., Wolff, D. B., Adler, R. F., Gu, G., Hong, Y., Bowman, K. P., and Stocker, E. F.: The TRMM Multisatellite Precipitation Analysis (TMPA): Quasi-Global, Multiyear, Combined-Sensor Precipitation Estimates at Fine Scales, J. Hydrometeorol., 8, 38-55, doi:10.1175/JHM560.1, 2007.

HYBAM: Fourth Scientific Meeting of the ORE HYBAM, Lima, Peru, 2011.

Klimeš, J., Vilímek, V., and Omelka, M.: Implications of geomorphological research for recent and prehistoric avalanches and related hazards at Huascaran, Peru, Nat. Hazards, 50, 193-209, doi:10.1007/s11069-008-9330-7, 2009.

Korup, O. and Clague, J. J.: Natural hazards, extreme events, and mountain topography, Quaternary Sci. Rev., 28, 977-990, doi:10.1016/j.quascirev.2009.02.021, 2009.

Lague, D., Hovius, N., and Davy, P.: Discharge, discharge variability, and the bedrock channel profile, J. Geophys. Res., 110, F04006, doi:10.1029/2004JF000259, 2005.

Laraque, A., Bernal, C., Bourrel, L., Darrozes, J., Christophoul, F., Armijos, E., Fraizy, P., Pombosa, R., and Guyot, J. L.: Sediment budget of the Napo River, Amazon basin, Ecuador and Peru, Hydrol. Process., 23, 3509-3524, doi:10.1002/hyp.7463, 2009.

Lavado, W., Ronchail, J., Labat, D., Espinoza, J. C., and Guyot, J. L.: A basin-scale analysis of rainfall and runoff in Peru (19692004): Pacific, Titicaca and Amazonas drainages, Hydrolog. Sci. J., 57, 1-18, doi:10.1080/02626667.2012.672985, 2012. 
Love, D., Clark, A., and Glover, K.: The Lithologic, Stratigraphic, and Structural Setting of the Giant Antamina CopperZinc Skarn Deposit, Ancash, Peru, Econ. Geol., 99, 887-916, doi:10.2113/econgeo.99.5.887, 2004.

Malamuda, B. D. and Turcotte, D. L.: The applicability of powerlaw frequency statistics to floods, J. Hydrol., 322, 168-180, doi:10.1016/j.jhydrol.2005.02.032, 2006.

Mark, B. and Seltzer, G.: Tropical glacier meltwater contribution to stream discharge: a case study in the Cordillera Blanca, Peru, J. Glaciol., 49, 271-281, 2003.

McMahon, G., Evia, J., Pasco-Font, A., and Sanchez, J.: An environmental study of artisanal, small, and medium mining in Bolivia, Chile, and Peru, World Bank, Washington, D.C., 429 pp., 1999.

McNulty, B. and Farber, D.: Active detachment faulting above the Peruvian flat slab, Geology, 30, 567-570, 2002.

Molina, A., Govers, G., Vanacker, V., Poesen, J., Zeelmaekers, E., and Cisneros, F.: Runoff generation in a degraded Andean ecosystem: interaction of vegetation cover and land use, Catena, 71, 357-370, 2007.

Molina, A., Govers, G., Poesen, J., Van Hemelryck, H., De Bievre, B., and Vanacker, V.: Environmental factors controlling spatial variation in sediment yield in central america mountain area, Geomorphology, 98, 176-186, 2008.

Montgomery, D. R.: Soil erosion and agricultural sustainability, P. Natl. Acad. Sci., 104, 13268-13272, 2007.

Montgomery, D. R., Balca, G., and Willett, S.: Climate, tectonics, and the morphology of the Andes, Geology, 29, 579-582, doi:10.1130/0091-7613(2001)029<0579:CTATMO>2.0.CO;2, 2001.

Morera, S. B.: Dinámica de la producción de sedimentos en la cuenca del río Santa, Magíster Scientiae en Recursos Hídricos, Universidad Nacional Agraria La Molina, Lima, Perú, 98 pp., 2010.

Pépin, E.: Erosion actuelle des Andes: Contrôle tectonique et/ou climatique sur les bassins du versant Atlantique, Master 2, Universite Toulouse III - Paul Sabatier Toulouse, 29 pp., 2007.

Pépin, E., Carretier, S., Guyot, J. L., and Escobar, F.: Specific suspended sediment yields of the Andean rivers of Chile and their relationship to climate, slope and vegetation, Hydrolog. Sci. J., 57, 1190-1205, 2010.

Pépin, E., Guyot, J. L., Armijos, E., Bazan, H., Fraizy, P., Moquet, J. S., Noriega, L., Lavado, W., Pombosa, R., and Vauchel, P.: Climatic control on eastern Andean denudation rates (Central Cordillera from Ecuador to Bolivia), J. S. Am. Earth Sci., 44, 85-93, 2013.

Petersen, G.: Mining and Metallurgy in Ancient Peru, Reaching New Peaks in Geoscience, Denver, CO USA, 2010.

Racoviteanu, A., Manley, W., Arnaud, Y., and Williams, M.: Evaluating digital elevation models for glaciologic applications: An example from Nevado Coropuna, Peruvian Andes, Global Planet. Change, 59, 110-125, 2007.

Restrepo, J. D. and Kjerfve, B.: The Pacific and Caribbean Rivers of Columbia: water discharge, sediment transport, and dissolved loads, in: Environmental Geochemistry in Tropical and Subtropical Environments, edited by: Lacerda, D. L., Santelli, R., Duursma, E., and Abrao, J., Environmental Science, Springer Verlag, Berlin, 169-187, 2004.
Restrepo, J. D., Kjerfve, B., Hermelin, M., and Restrepo, J. C.: Factors controlling sediment yield in a major South American drainage basin: the Magdalena River, Colombia, J. Hydrol., 316, 213-232, 2006a.

Restrepo, J. D., Zapata, P., Díaz, J. M., Garzón-Ferreira, J., and García, C.: Fluvial fluxes into the Caribbean Sea and their impact on coastal ecosystems: The Magdalena River, Colombia, Global Planet. Change, 50, 33-49, doi:10.1016/j.gloplacha.2005.09.002, 2006b.

Rodríguez, E., Morris, C., and Belz, E.: A Global Assessment of the SRTM Performance, Photogramm. Eng. Rem. S., 72, 249-260, 2006.

Scheel, M. L. M., Rohrer, M., Huggel, Ch., Santos Villar, D., Silvestre, E., and Huffman, G. J.: Evaluation of TRMM Multisatellite Precipitation Analysis (TMPA) performance in the Central Andes region and its dependency on spatial and temporal resolution, Hydrol. Earth Syst. Sci., 15, 2649-2663, doi:10.5194/hess-15-2649-2011, 2011.

Schwartz, D. P.: Paleoseismicity and neotectonics of the Cordillera Blanca Fault Zone, northern Peruvian Andes, J. Geophys. Res., 93, 4712-4730, 1988.

Smith, R. B.: The influence of mountains on the atmosphere, Adv. Geophys., 21, 87-230, 1979.

SRTM - NASA, NIMA, DLR, and ASI: Shuttle Radar Topography Mission (SRTM) Elevation Dataset:, US Geological Survey, Sioux Falls, SD, 2002.

Tao, C., Qiongfang, L., Meixiu, Y., Guobin, L., Lipeng, C., and Xie, W.: Investigation into the impacts of land-use change on sediment yield characteristics in the upper Huaihe River basin, China, Phys. Chem. Earth Pt. A/B/C, 53-54, 1-9, doi:10.1016/j.pce.2011.08.023, 2012.

Tarras-Wahlberg, N. H. and Lane, S. N.: Suspended sediment yield and metal contamination in a river catchment affected by El Niño events and goldmining activities: The Puyango river basin, southern Ecuador, Hydrol. Process., 17, 3101-3123, doi:10.1002/hyp.1297, 2003.

Tote, C., Govers, G., Van Kerckhoven, S., Filiberto, I., Verstraeten, G., and Eerens, H.: Effect of ENSO events on sediment production in a large coastal basin in northern Peru, Earth Surf. Proc. Land., 36, 1776-1788, doi:10.1002/esp.2200, 2011.

Turcotte, D. L. and Greene, L.: A scale-invariant approach to flood frequency analysis, Stoch. Hydrol. Hydraul., 7, 33-40, 1993.

Turowski, J. M., Rickenmann, D., and Dadson, S. J.: The partitioning of the total sediment load of a river into suspended load and bedload: a review of empirical data, Sedimentol., 57, 1126-1146, doi:10.1111/j.1365-3091.2009.01140.x, 2010.

United Nations: The water resources of Latin America and the Caribbean: Planning, hazards and pollution, United Nations Economic Commission for Latin America and the Caribbean, Santiago, Chile, 1990.

Vanacker, V., Molina, A., Govers, G., Poesen, J., Dercon, G., and Deckers, S: River channel response to short-term human-induced change in connectivity in Andean ecosystems, Geomorphology, 72, 340-353, doi:10.1016/j.geomorph.2005.05.013, 2005.

Vargas, G., Rutllant, J., and Ortlieb, L.: ENSO climate teleconnections andmechanisms for Holocene debris flows along the hyperarid coast ofwestern South America (17-24 ${ }^{\circ}$ S), Earth Planet. Sc. Lett., 249, 467-483, doi:10.1016/j.eps1.2006.07.022, 2006. 
Vuille, M., Kaser, G., and Irmgard, J.: Glacier mass balance variability in the Cordillera Blanca, Peru and its relationship with climate and the large-scale circulation, Global Planet. Change, 62, 14-28, doi:10.1016/j.gloplacha.2007.11.003, 2008.

Ward, P., Bales, R., Verstraeten, G., Renssen, H., and Vandenberghe, J.: The impact of land use and climate change on late Holocene and future suspended sediment yield of the Meuse catchment, Geomorphology, 103, 89-400, doi:10.1016/j.geomorph.2008.07.006, 2009.

Wilson, J., Reyes, L., and Garayar, J.: Geología de los cuadrangulos de Mollebamba, Tayabamba, Huaylas, Pomabamba, Carhuaz, y Huari. Boletín, Servicio de Geología y Minería, Peru, 16 pp., 1967.
Young, K. and Lipton, J.: Adaptive governance and climate change in the tropical highlands of western South America, Climatic Change, 78, 63-102, doi:10.1007/s10584-006-9091-9, 2006.

Zapata, M., Arnaud, Y., and Gallaire, R.: Inventario de glaciares de la Cordillera Blanca, 13th IWRA World Water Congreso, Montpellier, France, 2008. 